\title{
Large Changes in Fiscal Policy: Taxes versus Spending
}

\section{Citation}

Alesina, Alberto, and Silvia Ardagna. 2010. "Large Changes in Fiscal Policy: Taxes Versus

Spending." Tax Policy and the Economy 24 (1) (January): 35-68. doi:10.1086/649828.

\section{Published Version}

$10.1086 / 649828$

\section{Permanent link}

http://nrs.harvard.edu/urn-3:HUL.InstRepos:22801844

\section{Terms of Use}

This article was downloaded from Harvard University's DASH repository, and is made available under the terms and conditions applicable to Open Access Policy Articles, as set forth at http:// nrs.harvard.edu/urn-3:HUL.InstRepos:dash.current.terms-of-use\#OAP

\section{Share Your Story}

The Harvard community has made this article openly available.

Please share how this access benefits you. Submit a story.

Accessibility 


\title{
Large Changes in Fiscal Policy: Taxes versus Spending
}

\author{
Alberto Alesina, Harvard University and NBER \\ Silvia Ardagna, Harvard University and NBER
}

\section{Executive Summary}

We examine the evidence on episodes of large stances in fiscal policy, in cases of both fiscal stimuli and fiscal adjustments in OECD countries from 1970 to 2007. Fiscal stimuli based on tax cuts are more likely to increase growth than those based on spending increases. As for fiscal adjustments, those based on spending cuts and no tax increases are more likely to reduce deficits and debt over GDP ratios than those based on tax increases. In addition, adjustments on the spending side rather than on the tax side are less likely to create recessions. We confirm these results with simple regression analysis.

\section{Introduction}

As a result of the fiscal response to the financial crisis of 2007-9 the United States will experience the largest increases in deficits and debt accumulation in peacetime. Virtually all other OECD countries will also face fiscal imbalances of various sizes. After the large reduction in government deficits of the 1990s and early new century, public finances in the OECD are back in the deep red.

Only a few months ago the key policy question was whether tax cuts or spending increases were a better recipe for the stimulus plan in the United States and other countries as well. By and large these decisions have been made, and we are in the process of observing the results. The next question governments all over the world will face next year, assuming, as it seems likely, that a recovery next year will be under way, is how to stop the growth of debt and return to more "normal" public finances.

The first question, namely, whether tax cuts or spending increases are more expansionary, is a critical one, and economists strongly disagree about the answer. It is fair to say that we know relatively little about the effect of fiscal policy on growth and in particular about the so-called 
fiscal multipliers, namely, how much one dollar of tax cuts or spending increases translates in terms of GDP. The issue is very politically charged as well, since right of center economists and policy makers believe in tax cuts and the left of center ones believe in spending increases. While the differences are often rooted in different views about the role of government and inequality, not so much about the size of fiscal multipliers, both sides also wish to "sell" their prescription as growth enhancing and more so than the other policy. Unfortunately, both sides cannot be right at the same time!

As far as reduction of large public debts, the lesson from history is reasonably optimistic. Large debt/GDP ratios have been cut relatively rapidly by sustained growth. This was the case of post-World War II public debts in belligerent countries; it was also the case of the United States in the 1990s when without virtually any increase in tax rates or significant spending cuts, a large deficit turned into a large surplus. ${ }^{1}$ In the United Kingdom the debt/GDP ratio at the end of World War II was over $200 \%$, but that country did not suffer a financial crisis because of its historically credible fiscal stance, and the debt was gradually and relatively rapidly reduced. However, it would probably be too optimistic to expect another decade like the 1990s ahead of us; that kind of sustained growth would certainly do a lot to reduce the debt/GDP ratio, but the lower growth we will most likely experience will do much less. Inflation also has the effect of chipping away the real value of the debt, but it may be a medicine worse than the disease. While a period of controlled and moderate inflation would have the potential to reduce the real value of outstanding debt, pursuing such a strategy would run the risk of rising or uncontrolled inflation. It took a sharp recession in the early 1980s to eliminate the great inflation of the 1970s, and the last thing we need is another major recession in the medium run. The post-World War I hyperinflations are certainly not on the horizon, but we should keep them in the back of our mind as an extreme case of debt-induced runaway inflation.

If growth alone cannot do it and inflating away the debt carries substantial risks, we are left with the accumulation of budget surpluses to rein in the debt in the next several years in the postcrisis era. But then the same question returns: is raising taxes or cutting spending more likely to result in a stable fiscal outlook?

This is precisely what this paper is about. We focus on large changes in fiscal policy stance, namely, a large increase or reduction of budget deficits, and we look at what effects they had on both the economy and the dynamics of the debt. In particular, for the case of budget expansions (increase in deficits or reduction of surpluses) we look at which have been 
more expansionary on growth. On fiscal adjustments (deficit reductions) we consider their effect on a medium-term stabilization/reduction of the debt/GDP level and their cost in terms of a downturn in the economy. We focus only on large fiscal changes because we try to isolate changes in fiscal policy that are policy induced as opposed to cyclical fluctuations of the deficits, which in any event we try to cyclically adjust. Our methodology is rather simple. We identify episodes of large changes in fiscal policy. Obviously the decision of when to engage in such policy changes is not exogenous to the state of public finances and of the economy. But up to a point the decision of whether to act on the spending side or the revenue side is largely political and due to bargaining among political and pressure groups. The uncertainty about the size of fiscal multipliers makes this discussion even less constrained by solid economic arguments. Thus we cannot offer new measures of fiscal multipliers, but we can look at what effects different approaches (spending vs. revenue side) have had during and after large fiscal changes.

Our results suggest that tax cuts are more expansionary than spending increases in the cases of a fiscal stimulus. For fiscal adjustments we show that spending cuts are much more effective than tax increases in stabilizing the debt and avoiding economic downturns. In fact, we uncover several episodes in which spending cuts adopted to reduce deficits have been associated with economic expansions rather than recessions. We also investigate which components of taxes and spending affect the economy more in these large episodes, and we try to uncover channels running through private consumption and/or investment.

The present paper is more directly related to several ones written in the early 1990s using an approach similar to ours. Giavazzi and Pagano (1990) were the first to argue that fiscal adjustments (deficit reductions) large, decisive, and on the spending side could be expansionary. This was the case of Ireland and Denmark in the 1980s, which were the episodes studied by Giavazzi and Pagano, but there were others, as those discussed and analyzed by Alesina and Ardagna (1998). The same authors and Alesina and Perotti (1997) investigate various episodes of fiscal adjustments reaching conclusions similar to that of the present paper. But in this paper we have many more episodes and we use more compelling techniques. There is quite a rich literature that studies the determinants and economic outcomes of large fiscal adjustments. A nonexhaustive list includes McDermott and Wescott (1996), Giavazzi, Jappelli, and Pagano (2000), von Hagen and Strauch (2001), von Hagen, Hallett, and Strauch (2002), Ardagna (2004), and Lambertini and Tavares (2005). Theoretically, expansionary effects of fiscal adjustments can go through both the demand 
and the supply sides. On the demand side, a fiscal adjustment may be expansionary if agents believe that the fiscal tightening generates a change in regime that "eliminates the need for larger, maybe much more disruptive adjustments in the future" (Blanchard 1990, 111). ${ }^{2}$ Current increases in taxes and/or spending cuts perceived as permanent, by removing the danger of sharper and more costly fiscal adjustments in the future, generate a positive wealth effect. Consumers anticipate a permanent increase in their lifetime disposable income, and this may induce an increase in current private consumption and in aggregate demand. The size of the increase in private consumption would depend, however, on the presence or absence of "liquidity-constrained" consumers. An additional channel through which current fiscal policy can influence the economy via its effect on agents' expectations is the interest rate. If agents believe that the stabilization is credible and avoids a default on government debt, they can ask for a lower premium on government bonds. Private demand components sensitive to the real interest rate can increase if the reduction in the interest rate paid on government bonds leads to a reduction in the real interest rate charged to consumers and firms. The decrease in the interest rate can also lead to the appreciation of stocks and bonds, increasing agents' financial wealth and triggering a consumption/ investment boom.

On the supply side, expansionary effects of fiscal adjustments work via the labor market and via the effect that tax increases and/or spending cuts have on the individual labor supply in a neoclassical model and on the unions' fallback position in imperfectly competitive labor markets (see Alesina and Ardagna [1998] and Alesina et al. [2002] for a review of the literature). In the latter context, the composition of current fiscal policy (whether the deficit reduction is achieved through tax increases or through spending cuts) is critical for its effect on the economy. On the one hand, a decrease in government employment reduces the probability of finding a job if not employed in the private sector, and a decrease in government wages decreases the worker's income if employed in the public sector. In both cases, the reservation utility of union members goes down and the wage demanded by the union for private-sector workers decreases, increasing profits, investment, and competitiveness. On the other hand, an increase in income taxes or Social Security contributions that reduces the net wage of the worker leads to an increase in the pretax real wage faced by the employer, squeezing profits, investment, and competitiveness.

This is not the place to review in detail the large literature on the effect of fiscal policy on the economy. It is worth mentioning that Romer and 
Romer (2007) also follow an event approach even though they identify events of large discretionary changes in fiscal policy in a very different way from ours. Using a variety of narrative sources, they identify changes in the U.S. federal tax legislation that are undertaken either to solve an inherited budget deficit problem or to achieve long-run goals and estimate the effect of such changes on real output in a vector autoregressive (VAR) framework. They find that an increase in taxation by $1 \%$ of GDP reduces output in the next 3 years by a maximum of about $3 \%$ and that the effect is smaller when the only changes in taxes considered are those taken to reduce past budget deficits. As Romer and Romer, we also find that tax increases are contractionary, but the magnitudes of our results are difficult to compare to theirs. In our estimates, we find that a $1 \%$ increase in the cyclically adjusted tax revenue decreases real growth by less than one-third of a percentage point. However, we estimate a very different specification, and contrary to Romer and Romer, our approach also controls for changes in government spending undertaken to reduce budget deficits as well as for changes in taxation.

Blanchard and Perotti (2002) use structurally VAR techniques to identify exogenous changes in fiscal policy and estimate fiscal multipliers both on the tax and on the spending side of the government. They find that positive government spending shocks increase output and consumption and decrease investment, whereas positive tax shocks have a negative effect on output, consumption, and investment. Mountford and Uhlig (2008) use a very different identification approach, and while they also find that both taxes and spending increases have a negative effect on private investment (as previously shown by Alesina et al. [2002]), they show that spending increases do not generate an increase in consumption and that deficit-financed tax cuts are the most effective way to stimulate the economy. The result of a positive effect of government spending shocks on private consumption is also challenged by Ramey (2009). She finds that, when the timing of the news about government spending increases is captured with a narrative approach and not with delay as in a VAR approach, consumption declines after increases in government spending. Our results on the negative correlation between both spending and tax increases on GDP growth are clearly consistent with the results of these papers using methodological approaches quite different from ours.

A substantial literature has investigated political and institutional effects on fiscal policy and in particular on the propensity of different parties in different institutional settings to prolong fiscal imbalances or to rein them in promptly. On delayed fiscal adjustments, see Alesina and Drazen (1991); on politico-institutional effects, like the role of electoral 
laws, on the occurrence of loose or tight fiscal policy, see Milesi-Ferretti, Perotti, and Rostagno (2002) and Persson and Tabellini (2003). Alesina, Perotti, and Tavares (1998), using an approach similar to that of the present paper and based on "episodes," investigate which parties are more or less likely to run in fiscal stimuli or fiscal adjustments. One criticism that one could raise to the literature on voting rules and institutions on fiscal imbalances is that rules are not exogenous, and third factors may indeed explain the adoption of both certain voting rules (like proportional representation) and fiscal policy, a point discussed in Alesina and Glaeser (2004) informally and Aghion, Alesina, and Trebbi (2004) more formally. We do not pursue in the present paper this politico-economic analysis.

This paper is organized as follows. Section II discusses our data and the definition of episodes that we adopt. Section III presents basis statistics on the episodes showing rather striking results. Section IV shows some regression analysis, which, although it has no pretense of having solved causality problems, reinforces the results obtained by the simple statistics of Section III. Section V presents conclusions.

\section{Data, Methodology, and Definitions}

\section{A. Methodology}

Our approach is very simple. We identify major changes in fiscal policy, either expansionary (deficit increases or surplus reductions) or the opposite. Obviously the decision about whether to engage in these policy changes is endogenous to the state of the economy and of the finances. However, we assume that at least up to a point the decision of whether or not to act on the spending side or the revenue side of the government is dictated by political preferences and political bargaining, which is, at least to a point, exogenous to the economy and is generated by ideological or policy preferences. If we look at the debates following major fiscal changes and consider the high degree of uncertainty about the size of fiscal multipliers, this assumption holds some water. Thus our only emphasis is on the effects of different composition of fiscal stimuli and adjustments. We cannot and do not compute the size of fiscal multipliers. We only compare the effects of different compositions of major fiscal changes.

\section{B. Data and Sources}

We use a panel of OECD countries for a maximum time period from 1970 to 2007. The countries included in the sample are Australia, Austria, 
Belgium, Canada, Denmark, Finland, France, Germany, Greece, Ireland, Italy, Japan, Netherlands, New Zealand, Norway, Portugal, Spain, Sweden, Switzerland, United Kingdom, and United States. All fiscal and macroeconomic data are taken from the OECD Economic Outlook Database number 84 .

Our approach identifies episodes of large changes in the fiscal stance and studies the behavior of fiscal and macroeconomic variables around those episodes to investigate whether different characteristics of fiscal packages are correlated with different macroeconomic outcomes. More specifically, we focus both on the size of the fiscal packages (i.e., the magnitude of the change of the government deficit) and on their composition (i.e., the percentage change of the main government budget items relative to the total change), and we investigate whether large fiscal stimuli and adjustments that differ in size and composition are associated with booms or economic recessions (as defined below) and whether governments that implement different types of fiscal adjustments are successful/ unsuccessful in reducing government debt.

We use a cyclically adjusted value of the fiscal variables to leave aside variations of the fiscal variables induced by business cycle fluctuations. The cyclical adjustment is based on the method proposed by Blanchard (1993). It is a simple method and is rather transparent, which corrects various components of the government budget for year-to-year changes in the unemployment rate. More precisely, the cyclically adjusted value of the change in a fiscal variable is the difference between a measure of the fiscal variable in period $t$ computed as if the unemployment rate were equal to the one in $t-1$ and the actual value of the fiscal variable in year $t-1 .{ }^{3} \mathrm{We}$ prefer this method to more complicated measures like those produced by the OECD because the latter are a bit of a black box based on many assumptions about fiscal multipliers on which there is much uncertainty. On the basis of our previous work (Alesina and Ardagna 1998), we are confident that for the large episodes that we consider the details of how to adjust for the cycle do not matter much for the qualitative nature of the results. In fact, even not correcting at all would give similar results. ${ }^{4}$

\section{Definition of the Episodes}

To identify episodes of fiscal adjustments and fiscal stimuli we focus on large changes of fiscal policy and use the following rule.

Definition 1 (Fiscal adjustments and stimuli). A period of fiscal adjustment (stimulus) is a year in which the cyclically adjusted primary balance improves (deteriorates) by at least $1.5 \%$ of GDP. 
These are rather demanding criteria, which rule out small, but prolonged, adjustments/stimuli. We have chosen them because we are particularly interested in episodes that are very sharp and large and clearly indicate a change in the fiscal stance. This definition misses fiscal adjustments and stimuli that are small in each year but are prolonged for several years. It would be quite difficult to come up with a definition that captured the many possible patterns of multiyear small adjustments. Thus, the study of these episodes gives a clue about what happens with sharp and brief changes in the fiscal stance.

We use the primary deficit (i.e., the difference between current and capital spending, excluding interest rate expenses paid on government debt, and total tax revenue $)^{5}$ rather than the total deficit to avoid the situation in which episodes selected result from the effect that changes in interest rates have on total government expenditures. Using these criteria, we try to focus as much as possible on episodes that do not result from the automatic response of fiscal variables to economic growth or monetary policy induced changes on interest rates, but they should reflect discretionary policy choices of fiscal authorities. Needless to say, there can still be an endogeneity issue related to the occurrence of fiscal adjustments and expansions because, in principle, discretionary policy choices of fiscal authorities can be affected by countries' macroeconomic conditions. However, note that the budget for the current year is approved during the second half of the previous year, and even though additional measures can be taken during the course of the year, they usually become effective with some delay, generally toward the end of the fiscal year.

Definition 1 selects 107 periods of fiscal adjustments (15.1\% of the observations in our sample) and 91 periods of fiscal stimuli (12.9\% of the observations in our sample). Appendix table B1 lists all of them. Of the 107 episodes of fiscal adjustments, 65 last only for one period; the rest are multiperiod adjustments. The majority of the latter (13) last for 2 consecutive years, four are 3-year adjustments, and Denmark's 1983-86 fiscal stabilization is the only episode lasting 4 consecutive years. As for fiscal stimuli, 52 episodes last one period, in 12 cases the stimulus continues in the second year as well, and in five cases definition 1 selects fiscal stimuli that last for 3 consecutive years.

We are interested in two outcomes of very tight and very loose fiscal policies: whether they are associated with an expansion in economic activity during and in their immediate aftermath and whether they are associated with a reduction in the public debt-to-GDP ratio. Thus, an episode is defined as expansionary according to definition 2 and successful according to definition 3; we define as contractionary/unsuccessful all the 
episodes of fiscal stimuli and adjustments that are not expansionary/ successful according to these definitions.

Definition 2 (Expansionary fiscal adjustments and fiscal stimuli). An episode of fiscal adjustment (fiscal stimulus) is expansionary if the average growth rate of GDP, different from the Group of 7 (G7) average (weighted by GDP weights), in the first period of the episode and in the 2 years after is greater than the value of the 75 th percentile of the same variable empirical density in all episodes of fiscal adjustments (fiscal stimuli).

This definition selects 26 years of expansionary periods during fiscal adjustments (3.7\% of the observations of the entire OECD sample) and 20 years of expansionary periods during fiscal stimuli $(2.8 \%$ of the observations of the entire OECD sample). See appendix table B2 for a list.

Definition 3 (Successful fiscal adjustments). A period of fiscal adjustment is successful if the cumulative reduction of the debt-to-GDP ratio 3 years after the beginning of a fiscal adjustment is greater than 4.5 percentage points (the value of the 25 th percentile of the change of the debt-toGDP ratio empirical density in all episodes of fiscal adjustments). ${ }^{6}$

This definition selects 17 periods of successful fiscal adjustments $(2.7 \%$ of the observations of the entire OECD sample). In appendix table B2 we list all the episodes.

We have experimented with variation of the threshold of these definitions, but the results are robust; that is, they do not change significantly as a result of small changes in the definitions. A 1.5 change in deficits in a year is sufficiently high to eliminate years of "business as usual" in which fluctuations of the deficits may just be only cyclical. However, it is not so large as to have very few data points. Also, our "horizon" for the definition of "expansionary" and "success" is relatively short. Choosing a longer horizon has two problems. First, one loses many observations at the end of the sample; second, and more important, choosing a longer horizon makes the connection between the episodes and economic outcomes several years later more tenuous, given the extent of intervening factors. Finally, note that according to definitions 2 and 3, multiyear fiscal adjustments and stimuli are considered as a "single" episode because the length of the time horizon chosen for the definition of "expansionary" and "success" starts from the first year of the episode. Alesina and Ardagna (1998) and Alesina et al. (1998) instead consider each year of a multiyear period as a single episode. This implies that, in a multiyear episode, some years can be expansionary and some contractionary; some can be successful and some unsuccessful. While we have no reason to prefer one choice over the other, we find it reassuring that results are 
robust to these alternative methods used to select expansionary and successful episodes that last more than 1 consecutive year. ${ }^{7}$

\section{Basic Statistics}

\section{A. Fiscal Stimuli}

Let us begin by analyzing what happens with fiscal stimuli, namely, whether we can detect differences in the effects of fiscal packages depending on their composition on the economy. Table 1 shows the composition in terms of spending components and revenue components of the 20 years of expansionary fiscal stimulus packages versus the others. In tables $1-6$, the period $[T-2, T-1]$ is the 2-year period preceding the first year of a fiscal stimulus/adjustment. The period $[T]$ is the first year, and the period $[T+1, T+2]$ is the 2-year period following the beginning of an episode. ${ }^{8}$ All the variables in the tables are yearly averages.

The most striking result of this table is that in expansionary episodes total spending increases by roughly $1 \%$ of GDP whereas revenues fall by more than $2.5 \%$ of GDP. In contractionary episodes, total spending goes up by close to $3 \%$ of GDP whereas revenues are roughly constant in terms of GDP. This correlation seems to suggest that stimulus packages used on the spending side do not work or at least not as well as those based on spending increases. In terms of components of spending, we note that there is no difference between expansionary and contractionary episodes regarding public investment, which goes up by roughly the same amount in ratios of GDP. All the other components of primary spending and, in particular, transfers go up much more in contractionary episodes. This suggests that the non-public investment components of the budget are those that explain the different correlation with growth. As for revenues, note the large cut in income taxes in expansionary stimuli and the slight increase in contractionary ones. Not surprisingly, the debt over GDP ratio goes up less in expansionary episodes since the denominator increases more.

Figure 1 offers a striking visual image of the different compositions in terms of revenues and spending of expansionary and contractionary episodes. The first two comparisons of total spending and revenues are rather striking even visually. In table 2 we look at the different components of GDP to check whether there are differences in composition between expansionary and contractionary episodes. The first two rows, which refer to GDP growth, are somewhat obvious since they reflect the selection criteria of these episodes. All the components of aggregate 
Table 1

Fiscal Stimuli: Size and Composition

\begin{tabular}{|c|c|c|c|c|c|c|c|c|}
\hline & \multicolumn{4}{|c|}{ Expansionary } & \multicolumn{4}{|c|}{ Contractionary } \\
\hline & $\begin{array}{c}{[T-2-} \\
T-1] \\
(1)\end{array}$ & $\begin{array}{l}T \\
(2)\end{array}$ & $\begin{array}{c}{[T+1-} \\
T+2] \\
\quad(3)\end{array}$ & $(3)-(1)$ & $\begin{array}{c}{[T-2-} \\
T-1] \\
\quad(1)\end{array}$ & $\begin{array}{c}T \\
(2)\end{array}$ & $\begin{array}{c}{[T+1-} \\
T+2] \\
\quad(3)\end{array}$ & $(3)-(1)$ \\
\hline Debt & $\begin{array}{c}50.28 \\
(9.03)\end{array}$ & $\begin{array}{l}50.52 \\
(9.09)\end{array}$ & $\begin{array}{l}51.1 \\
(9.48)\end{array}$ & .82 & $\begin{array}{c}60.79 \\
(5.18)\end{array}$ & $\begin{array}{l}62.38 \\
(5.18)\end{array}$ & $\begin{array}{l}63.3 \\
(4.46)\end{array}$ & 2.51 \\
\hline Change in debt & $\begin{array}{l}-1.02 \\
(1.47)\end{array}$ & $\begin{array}{c}.48 \\
(1.12)\end{array}$ & $\begin{array}{c}.53 \\
(1.24)\end{array}$ & 1.55 & $\begin{array}{l}-.29 \\
(.59)\end{array}$ & $\begin{array}{l}2.24 \\
(.67)\end{array}$ & $\begin{array}{l}2.21 \\
(.68)\end{array}$ & 2.50 \\
\hline Total deficit & $\begin{array}{c}-1.04 \\
(1.62)\end{array}$ & $\begin{array}{c}2.19 \\
(1.65)\end{array}$ & $\begin{array}{l}3.27 \\
(1.24)\end{array}$ & 4.31 & $\begin{array}{l}1.5 \\
(.72)\end{array}$ & $\begin{array}{l}3.79 \\
(.74)\end{array}$ & $\begin{array}{l}3.97 \\
(.71)\end{array}$ & 2.47 \\
\hline Primary deficit & $\begin{array}{r}-2.01 \\
(.82)\end{array}$ & $\begin{array}{l}1.16 \\
(.92)\end{array}$ & $\begin{array}{l}1.61 \\
(.91)\end{array}$ & 3.62 & $\begin{array}{l}-.3 \\
(.45)\end{array}$ & $\begin{array}{l}1.99 \\
(.48)\end{array}$ & $\begin{array}{l}2.13 \\
(.41)\end{array}$ & 2.43 \\
\hline Primary expenditures & $\begin{array}{l}36.79 \\
(1.73)\end{array}$ & $\begin{array}{l}37.72 \\
(1.64)\end{array}$ & $\begin{array}{l}37.84 \\
(1.66)\end{array}$ & 1.05 & $\begin{array}{r}40.08 \\
(.94)\end{array}$ & $\begin{array}{r}42.22 \\
(.94)\end{array}$ & $\begin{array}{l}42.92 \\
(1.00)\end{array}$ & 2.84 \\
\hline Transfers & $\begin{array}{l}14.93 \\
(1.03)\end{array}$ & $\begin{array}{l}14.88 \\
(1.01)\end{array}$ & $\begin{array}{l}15.11 \\
(1.04)\end{array}$ & .18 & $\begin{array}{r}16.83 \\
(.60)\end{array}$ & $\begin{array}{r}17.28 \\
(.58)\end{array}$ & $\begin{array}{r}18.05 \\
(.57)\end{array}$ & 1.22 \\
\hline $\begin{array}{l}\text { Government wage } \\
\text { expenditures }\end{array}$ & $\begin{array}{r}10.62 \\
(.52)\end{array}$ & $\begin{array}{r}10.74 \\
(.47)\end{array}$ & $\begin{array}{r}10.94 \\
(.50)\end{array}$ & .32 & $\begin{array}{r}11.78 \\
(.41)\end{array}$ & $\begin{array}{r}12.2 \\
(.43)\end{array}$ & $\begin{array}{r}12.58 \\
(.46)\end{array}$ & .80 \\
\hline $\begin{array}{l}\text { Government nonwage } \\
\text { expenditures }\end{array}$ & $\begin{array}{l}6.81 \\
(.49)\end{array}$ & $\begin{array}{l}6.96 \\
(.49)\end{array}$ & $\begin{array}{l}6.97 \\
(.55)\end{array}$ & .16 & $\begin{array}{l}7.73 \\
(.29)\end{array}$ & $\begin{array}{l}8.15 \\
(.28)\end{array}$ & $\begin{array}{l}8.18 \\
(.31)\end{array}$ & .45 \\
\hline Subsidies & $\begin{array}{l}2.03 \\
(.33)\end{array}$ & $\begin{array}{l}2.09 \\
(.32)\end{array}$ & $\begin{array}{l}2.24 \\
(.37)\end{array}$ & .21 & $\begin{array}{l}1.82 \\
(.13)\end{array}$ & $\begin{array}{l}1.93 \\
(.14)\end{array}$ & $\begin{array}{l}1.93 \\
(.15)\end{array}$ & .11 \\
\hline $\begin{array}{l}\text { Government } \\
\text { investment }\end{array}$ & $\begin{array}{l}2.26 \\
(.37)\end{array}$ & $\begin{array}{l}3.05 \\
(.38)\end{array}$ & $\begin{array}{l}2.58 \\
(.37)\end{array}$ & .32 & $\begin{array}{l}1.95 \\
(.19)\end{array}$ & $\begin{array}{l}2.67 \\
(.27)\end{array}$ & $\begin{array}{l}2.21 \\
(.21)\end{array}$ & .26 \\
\hline Total revenue & $\begin{array}{l}38.8 \\
(1.90)\end{array}$ & $\begin{array}{l}36.56 \\
(1.83)\end{array}$ & $\begin{array}{l}36.23 \\
(2.00)\end{array}$ & -2.57 & $\begin{array}{l}40.38 \\
(1.15)\end{array}$ & $\begin{array}{l}40.23 \\
(1.12)\end{array}$ & $\begin{array}{l}40.8 \\
(1.07)\end{array}$ & .42 \\
\hline Income taxes & $\begin{array}{l}10.89 \\
(1.10)\end{array}$ & $\begin{array}{l}9.2 \\
(.98)\end{array}$ & $\begin{array}{c}9.03 \\
(1.08)\end{array}$ & -1.86 & $\begin{array}{r}11.02 \\
(.74)\end{array}$ & $\begin{array}{c}11.21 \\
(.71)\end{array}$ & $\begin{array}{r}11.26 \\
(.67)\end{array}$ & .24 \\
\hline Business taxes & $\begin{array}{l}4.25 \\
(.83)\end{array}$ & $\begin{array}{l}3.37 \\
(.63)\end{array}$ & $\begin{array}{l}2.6 \\
(.33)\end{array}$ & -1.65 & $\begin{array}{l}3.03 \\
(.25)\end{array}$ & $\begin{array}{c}2.78 \\
(.20)\end{array}$ & $\begin{array}{l}2.74 \\
(.22)\end{array}$ & -.29 \\
\hline Indirect taxes & $\begin{array}{r}13.33 \\
(.61)\end{array}$ & $\begin{array}{r}12.57 \\
(.61)\end{array}$ & $\begin{array}{l}12.6 \\
(.69)\end{array}$ & -.73 & $\begin{array}{r}12.67 \\
(.39)\end{array}$ & $\begin{array}{l}12.5 \\
(.40)\end{array}$ & $\begin{array}{r}12.76 \\
(.36)\end{array}$ & .09 \\
\hline $\begin{array}{l}\text { Social Security } \\
\text { contributions }\end{array}$ & $\begin{array}{l}8.7 \\
(.94)\end{array}$ & $\begin{array}{l}8.93 \\
(.82)\end{array}$ & $\begin{array}{l}9.35 \\
(.89)\end{array}$ & .65 & $\begin{array}{r}11.08 \\
(.69)\end{array}$ & $\begin{array}{r}11.17 \\
(.68)\end{array}$ & $\begin{array}{r}11.36 \\
(.70)\end{array}$ & .28 \\
\hline
\end{tabular}

Source: OECD.

Note: Variables are in share of GDP. Total deficit, primary deficit, primary expenditures, transfers, total revenues, and all revenue items are cyclically adjusted variables. Standard deviations of the means are in parentheses. See app. A for the exact definitions of the variables.

demand grow more after the stimulus in expansionary episodes. This result is a bit different from that reported in Alesina and Ardagna (1998). In that sample the difference between the two types of episodes seemed concentrated on investment rather than on consumption. ${ }^{9}$ In this sample 


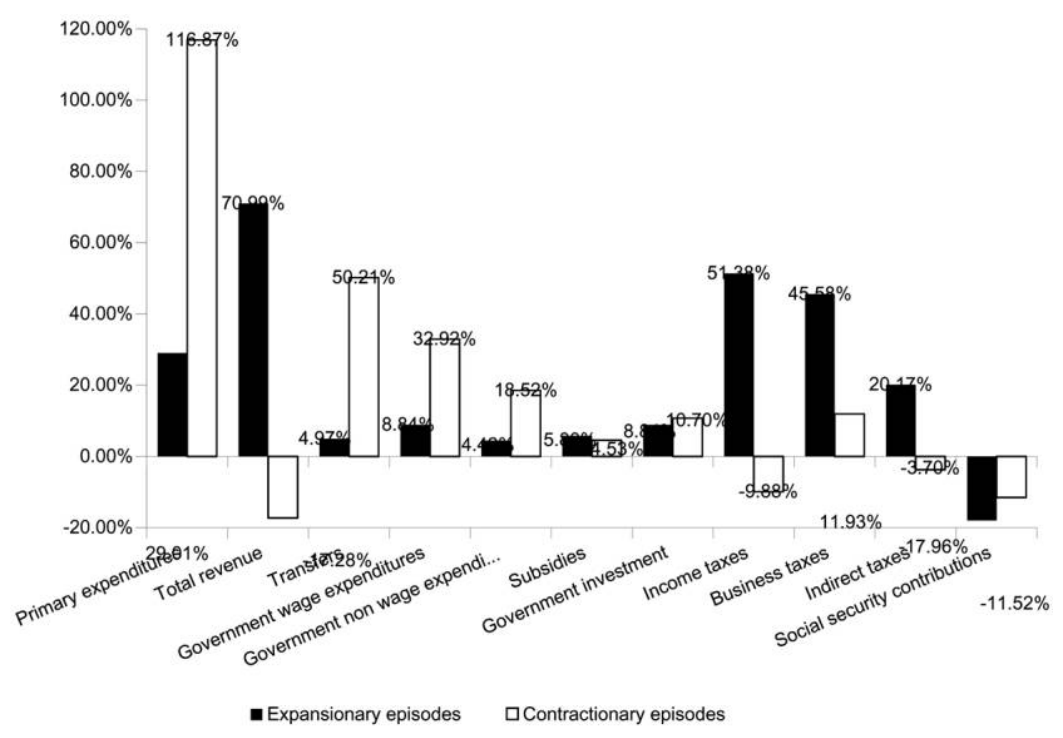

Fig. 1. Contribution of expenditure and revenue items to the fiscal stimuli. The figure shows the percentage of the increase (reduction) in the primary deficit (surplus) due to changes in spending and revenue items of the government budget. Positive values indicate that expenditure items increase and revenue items decrease, contributing to a worsening of the primary balance. Negative values indicate that expenditure items decrease and revenue items increase, contributing to an improvement of the primary balance.

both consumption and investment behave differently, both increasing in expansionary cases and declining in contractionary ones. This table also allows us to check whether the state of the economy before the adjustments was different in the two groups. In terms of domestic growth and relative to the G7 average, expansionary episodes occurred when growth was higher. As for the other components, the only significant difference seems to be in the trade balance. It is obviously cavalier to draw broad conclusions from this, but enormous differences in the preexisting state of the economy do not jump out from this table.

\section{B. Fiscal Adjustments}

Fiscal adjustments can be judged in two ways, as discussed above: first, whether they have been successful in significantly reducing deficits and the debt over GDP ratios and, second, whether they have been associated with a reduction in growth or not. Obviously, the two criteria are correlated since a growth-enhancing adjustment is more likely to be successful in reducing the debt/GDP ratio. However, the correlation is not perfect 
Table 2

Fiscal Stimuli and Growth

\begin{tabular}{|c|c|c|c|c|c|c|c|c|}
\hline & \multicolumn{4}{|c|}{ Expansionary } & \multicolumn{4}{|c|}{ Contractionary } \\
\hline & $\begin{array}{c}{[T-2-} \\
T-1] \\
\quad(1)\end{array}$ & $\begin{array}{c}T \\
(2)\end{array}$ & $\begin{array}{c}{[T+1-} \\
T+2] \\
\quad(3)\end{array}$ & $(3)-(1)$ & $\begin{array}{c}{[T-2-} \\
T-1] \\
\quad(1)\end{array}$ & $\begin{array}{c}T \\
(2)\end{array}$ & $\begin{array}{c}{[T+1-} \\
T+2] \\
\quad(3)\end{array}$ & $(3)-(1)$ \\
\hline G7 GDP growth & $\begin{array}{c}.39 \\
(.66)\end{array}$ & $\begin{array}{l}1.6 \\
(.53)\end{array}$ & $\begin{array}{l}2.03 \\
(.32)\end{array}$ & 1.64 & $\begin{array}{c}.2 \\
(.23)\end{array}$ & $\begin{array}{l}-.7 \\
(.23)\end{array}$ & $\begin{array}{c}-.74 \\
(.19)\end{array}$ & -.94 \\
\hline GDP growth & $\begin{array}{l}3.9 \\
(.65)\end{array}$ & $\begin{array}{c}3.77 \\
(.35)\end{array}$ & $\begin{array}{l}4.37 \\
(.32)\end{array}$ & .47 & $\begin{array}{l}2.89 \\
(.22)\end{array}$ & $\begin{array}{c}.93 \\
(.26)\end{array}$ & $\begin{array}{l}1.79 \\
(.27)\end{array}$ & -1.1 \\
\hline $\begin{array}{l}\text { Private } \\
\text { consumption } \\
\text { growth }\end{array}$ & $\begin{array}{l}3.49 \\
(.7)\end{array}$ & $\begin{array}{l}3.47 \\
(.61)\end{array}$ & $\begin{array}{l}3.72 \\
(.32)\end{array}$ & .23 & $\begin{array}{l}3.08 \\
(.22)\end{array}$ & $\begin{array}{l}1.54 \\
(.3)\end{array}$ & $\begin{array}{l}1.86 \\
(.29)\end{array}$ & -1.22 \\
\hline $\begin{array}{l}\text { Total } \\
\text { investment } \\
\text { growth }\end{array}$ & $\begin{array}{c}3.44 \\
(1.81)\end{array}$ & $\begin{array}{c}2.58 \\
(1.63)\end{array}$ & $\begin{array}{c}6.55 \\
(1.00)\end{array}$ & 3.11 & $\begin{array}{l}2.9 \\
(.59)\end{array}$ & $\begin{array}{r}-1.39 \\
(.82)\end{array}$ & $\begin{array}{c}.04 \\
(.64)\end{array}$ & -2.86 \\
\hline $\begin{array}{l}\text { Private } \\
\text { investment } \\
\text { growth }\end{array}$ & $\begin{array}{l}3.5 \\
(2.05)\end{array}$ & $\begin{array}{c}1.14 \\
(2.04)\end{array}$ & $\begin{array}{c}7.49 \\
(1.25)\end{array}$ & 3.99 & $\begin{array}{l}3.36 \\
(.73)\end{array}$ & $\begin{array}{l}-1.9 \\
(1.02)\end{array}$ & $\begin{array}{c}.07 \\
(.82)\end{array}$ & -3.29 \\
\hline $\begin{array}{l}\text { Business } \\
\text { investment } \\
\text { growth }\end{array}$ & $\begin{array}{c}5.51 \\
(2.06)\end{array}$ & $\begin{array}{c}2.5 \\
(3.21)\end{array}$ & $\begin{array}{c}7.64 \\
(1.53)\end{array}$ & 2.13 & $\begin{array}{c}6.73 \\
(1.44)\end{array}$ & $\begin{array}{c}-.34 \\
(1.34)\end{array}$ & $\begin{array}{c}-.78 \\
(1.07)\end{array}$ & -7.51 \\
\hline $\begin{array}{l}\text { Trade } \\
\text { balance }\end{array}$ & $\begin{array}{c}.53 \\
(2.07)\end{array}$ & $\begin{array}{r}.61 \\
(2.2)\end{array}$ & $\begin{array}{l}-1.9 \\
(2.11)\end{array}$ & -2.43 & $\begin{array}{c}.19 \\
(.7)\end{array}$ & $\begin{array}{l}-.2 \\
(.65)\end{array}$ & $\begin{array}{c}.14 \\
(.69)\end{array}$ & -.05 \\
\hline
\end{tabular}

since a fiscal adjustment may lead to a sharp reduction of the debt/GDP ratio because the numerator drops faster than the denominator. Episodes with this characteristic, that is, the ability to reduce the debt/GDP ratio, but also contractionary exist, for example, Netherlands in 1993, Norway in 1989, and Sweden in 1986-87.

Table 3 is organized in the same way as table 1 above. The expansionary episodes of fiscal adjustments are mostly characterized by spending cuts. Primary spending as a percentage of GDP falls by more than $2 \%$. Total revenues instead increase slightly by about $0.34 \%$ of GDP. However, in the case of contractionary fiscal adjustments, primary spending is cut by about $0.7 \%$ of GDP, whereas revenues increase by about $1.2 \%$ of GDP. Thus, fiscal adjustments occurring on the spending side have effects on growth superior to those based on increases in tax revenues. As far as the composition in components, probably the most striking difference between the two types of adjustments has to do with the role of transfers. In contractionary cases, transfers continue to grow as a percentage of GDP 
Table 3

Expansionary and Contractionary Fiscal Adjustments: Size and Composition

\begin{tabular}{|c|c|c|c|c|c|c|c|c|}
\hline & \multicolumn{4}{|c|}{ Expansionary } & \multicolumn{4}{|c|}{ Contractionary } \\
\hline & $\begin{array}{c}{[T-2-} \\
T-1] \\
(1)\end{array}$ & $\begin{array}{c}T \\
(2)\end{array}$ & $\begin{array}{c}{[T+1-} \\
T+2] \\
\quad(3)\end{array}$ & (3) $-(1)$ & $\begin{array}{c}{[T-2-} \\
T-1] \\
\quad(1)\end{array}$ & $\begin{array}{c}T \\
(2)\end{array}$ & $\begin{array}{c}{[T+1-} \\
T+2] \\
(3)\end{array}$ & (3) $-(1)$ \\
\hline Debt & $\begin{array}{c}59.86 \\
(5.52)\end{array}$ & $\begin{array}{c}57.53 \\
(5.22)\end{array}$ & $\begin{array}{l}54.1 \\
(5.07)\end{array}$ & -5.76 & $\begin{array}{c}69.15 \\
(4.04)\end{array}$ & $\begin{array}{l}71.8 \\
(4.23)\end{array}$ & $\begin{array}{c}69.52 \\
(4.25)\end{array}$ & .37 \\
\hline Change in debt & $\begin{array}{l}-1.46 \\
(1.03)\end{array}$ & $\begin{array}{l}-2.42 \\
(1.14)\end{array}$ & $\begin{array}{r}-2.3 \\
(.54)\end{array}$ & -.84 & $\begin{array}{l}3.28 \\
(.62)\end{array}$ & $\begin{array}{l}1.97 \\
(.54)\end{array}$ & $\begin{array}{l}1.28 \\
(.52)\end{array}$ & -2.00 \\
\hline Total deficit & $\begin{array}{c}3.61 \\
(1.09)\end{array}$ & $\begin{array}{c}1.33 \\
(1.18)\end{array}$ & $\begin{array}{l}.56 \\
(.98)\end{array}$ & -3.05 & $\begin{array}{l}5.67 \\
(.63)\end{array}$ & $\begin{array}{l}3.89 \\
(.70)\end{array}$ & $\begin{array}{l}4.14 \\
(.72)\end{array}$ & -1.53 \\
\hline Primary deficit & $\begin{array}{l}1.31 \\
(.77)\end{array}$ & $\begin{array}{c}-.84 \\
(.74)\end{array}$ & $\begin{array}{r}-1.23 \\
(.60)\end{array}$ & -2.54 & $\begin{array}{l}2.7 \\
(.40)\end{array}$ & $\begin{array}{l}.74 \\
(.43)\end{array}$ & $\begin{array}{l}.85 \\
(.39)\end{array}$ & -1.85 \\
\hline Primary expenditures & $\begin{array}{l}41.32 \\
(2.04)\end{array}$ & $\begin{array}{l}39.71 \\
(1.80)\end{array}$ & $\begin{array}{l}39.13 \\
(1.59)\end{array}$ & -2.19 & $\begin{array}{r}43.22 \\
(.98)\end{array}$ & $\begin{array}{r}42.47 \\
(.95)\end{array}$ & $\begin{array}{r}42.58 \\
(.93)\end{array}$ & -.64 \\
\hline Transfers & $\begin{array}{l}18.1 \\
(1.37)\end{array}$ & $\begin{array}{l}17.66 \\
(1.21)\end{array}$ & $\begin{array}{l}17.52 \\
(1.08)\end{array}$ & -.58 & $\begin{array}{r}17.95 \\
(.54)\end{array}$ & $\begin{array}{r}18.21 \\
(.54)\end{array}$ & $\begin{array}{c}18.42 \\
(.54)\end{array}$ & .47 \\
\hline $\begin{array}{l}\text { Government wage } \\
\text { expenditures }\end{array}$ & $\begin{array}{r}11.65 \\
(.53)\end{array}$ & $\begin{array}{c}11.41 \\
(.51)\end{array}$ & $\begin{array}{r}11.25 \\
(.46)\end{array}$ & -.40 & $\begin{array}{r}12.46 \\
(.40)\end{array}$ & $\begin{array}{r}12.25 \\
(.38)\end{array}$ & $\begin{array}{r}12.16 \\
(.36)\end{array}$ & -.30 \\
\hline $\begin{array}{l}\text { Government nonwage } \\
\text { expenditures }\end{array}$ & $\begin{array}{l}7.03 \\
(.53)\end{array}$ & $\begin{array}{l}6.91 \\
(.49)\end{array}$ & $\begin{array}{l}6.9 \\
(.48)\end{array}$ & -.13 & $\begin{array}{l}8.09 \\
(.27)\end{array}$ & $\begin{array}{l}8.1 \\
(.28)\end{array}$ & $\begin{array}{l}8.11 \\
(.28)\end{array}$ & .02 \\
\hline Subsidies & $\begin{array}{l}2.17 \\
(.33)\end{array}$ & $\begin{array}{l}1.95 \\
(.30)\end{array}$ & $\begin{array}{l}1.85 \\
(.28)\end{array}$ & -.32 & $\begin{array}{l}2.07 \\
(.13)\end{array}$ & $\begin{array}{l}1.98 \\
(.13)\end{array}$ & $\begin{array}{l}1.98 \\
(.14)\end{array}$ & -.09 \\
\hline $\begin{array}{l}\text { Government } \\
\text { investment }\end{array}$ & $\begin{array}{l}2.38 \\
(.29)\end{array}$ & $\begin{array}{l}1.77 \\
(.27)\end{array}$ & $\begin{array}{l}1.61 \\
(.25)\end{array}$ & -.77 & $\begin{array}{c}2.66 \\
(.18)\end{array}$ & $\begin{array}{l}1.95 \\
(.17)\end{array}$ & $\begin{array}{l}1.96 \\
(.14)\end{array}$ & -.70 \\
\hline Total revenue & $\begin{array}{l}40.02 \\
(1.99)\end{array}$ & $\begin{array}{l}40.56 \\
(1.90)\end{array}$ & $\begin{array}{l}40.36 \\
(1.84)\end{array}$ & .34 & $\begin{array}{r}40.52 \\
(.98)\end{array}$ & $\begin{array}{r}41.73 \\
(.94)\end{array}$ & $\begin{array}{r}41.73 \\
(.96)\end{array}$ & 1.21 \\
\hline Income taxes & $\begin{array}{l}10.62 \\
(1.04)\end{array}$ & $\begin{array}{l}10.59 \\
(1.07)\end{array}$ & $\begin{array}{r}10.35 \\
(.97)\end{array}$ & -.27 & $\begin{array}{r}11.45 \\
(.63)\end{array}$ & $\begin{array}{r}11.79 \\
(.63)\end{array}$ & $\begin{array}{r}11.93 \\
(.63)\end{array}$ & .48 \\
\hline Business taxes & $\begin{array}{l}2.92 \\
(.41)\end{array}$ & $\begin{array}{l}3.49 \\
(.51)\end{array}$ & $\begin{array}{l}3.58 \\
(.50)\end{array}$ & .66 & $\begin{array}{l}2.55 \\
(.17)\end{array}$ & $\begin{array}{c}2.88 \\
(.22)\end{array}$ & $\begin{array}{l}2.9 \\
(.25)\end{array}$ & .35 \\
\hline Indirect taxes & $\begin{array}{r}13.52 \\
(.46)\end{array}$ & $\begin{array}{r}13.61 \\
(.40)\end{array}$ & $\begin{array}{r}13.53 \\
(.40)\end{array}$ & .01 & $\begin{array}{r}12.44 \\
(.31)\end{array}$ & $\begin{array}{r}12.69 \\
(.30)\end{array}$ & $\begin{array}{r}12.65 \\
(.30)\end{array}$ & .21 \\
\hline $\begin{array}{l}\text { Social Security } \\
\text { contributions }\end{array}$ & $\begin{array}{c}9.63 \\
(1.01)\end{array}$ & $\begin{array}{l}9.52 \\
(.92)\end{array}$ & $\begin{array}{l}9.56 \\
(.89)\end{array}$ & -.07 & $\begin{array}{r}11.44 \\
(.61)\end{array}$ & $\begin{array}{r}11.52 \\
(.62)\end{array}$ & $\begin{array}{r}11.38 \\
(.66)\end{array}$ & -.06 \\
\hline
\end{tabular}

Source: OECD.

Note: Variables are in share of GDP. Total deficit, primary deficit, primary expenditures, transfers, total revenues, and all revenue items are cyclically adjusted variables. Standard deviations of the means are in parentheses. See app. A for the exact definitions of the variables.

of almost half of a percentage point. In expansionary episodes, instead, transfers fall by roughly the same amount. Thus, in between the two types of episodes there is a very large difference of $1 \%$ of GDP in the share of transfers. Looking at the composition of revenues, one is struck by 
income taxes: they go down quite significantly in expansionary adjustments and go up in contractionary ones. The difference between the two is almost 1 percentage point of GDP. This difference is by far the largest among revenue components.

Figure 2 is organized in the same way as figure 1, and even in this case visually the contrast between the two types of fiscal adjustments is quite obvious. When we look at the different components of GDP, we find that both consumption and investment grow more during expansionary episodes. We did not uncover any remarkable composition effects, along the same line as table 2 displayed for fiscal stimuli. These sample statistics are reported in table 4 , which is organized as table 2. The other interesting observation is that at least in terms of GDP growth and growth of its components, the preexisting conditions of expansionary and contractionary episodes look remarkably similar. One rather remarkable observation comes from comparing the growth performance during expansionary stimuli and expansionary adjustments: they are quite similar!

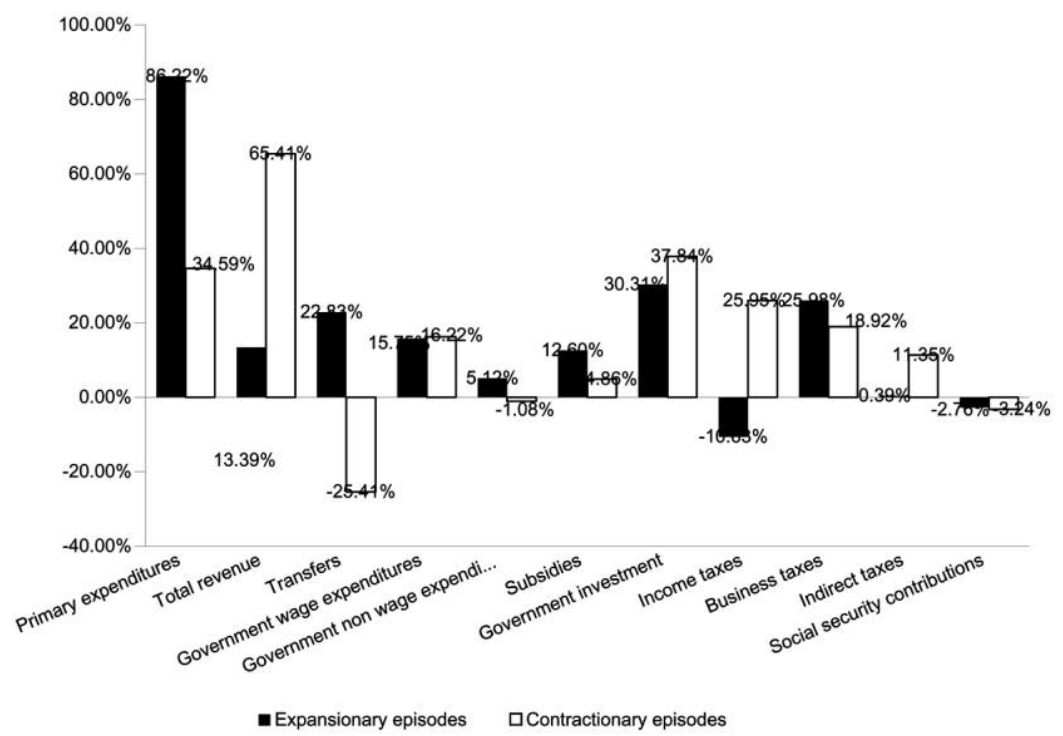

Fig. 2. Contribution of expenditure and revenue items to fiscal adjustments. The figure shows the percentage of the increase (reduction) in the primary deficit (surplus) due to changes in spending and revenue items of the governmen budget. Positive values indicate that expenditure items decrease and revenue items increase, contributing to an improvement of the primary balance. Negative values indicate that expenditure items increase and revenue items decrease, contributing to a worsening of the primary balance. 
Table 4

Expansionary and Contractionary Fiscal Adjustments and Growth

\begin{tabular}{|c|c|c|c|c|c|c|c|c|}
\hline & \multicolumn{4}{|c|}{ Expansionary } & \multicolumn{4}{|c|}{ Contractionary } \\
\hline & $\begin{array}{c}{[T-2-} \\
T-1] \\
\quad(1)\end{array}$ & $\begin{array}{l}T \\
(2)\end{array}$ & $\begin{array}{c}{[T+1-} \\
T+2] \\
\quad(3)\end{array}$ & (3) $-(1)$ & $\begin{array}{c}{[T-2-} \\
T-1] \\
(1)\end{array}$ & $\begin{array}{c}T \\
(2)\end{array}$ & $\begin{array}{c}{[T+1-} \\
T+2] \\
\quad(3)\end{array}$ & $(3)-(1)$ \\
\hline G7 GDP growth & $\begin{array}{c}.57 \\
(.55)\end{array}$ & $\begin{array}{l}1.49 \\
(.37)\end{array}$ & $\begin{array}{l}1.98 \\
(.24)\end{array}$ & 1.41 & $\begin{array}{c}-.32 \\
(.2)\end{array}$ & $\begin{array}{r}-.42 \\
(.2)\end{array}$ & $\begin{array}{c}-.49 \\
(.17)\end{array}$ & -.17 \\
\hline GDP growth & $\begin{array}{l}3.14 \\
(.56)\end{array}$ & $\begin{array}{l}4.73 \\
(.39)\end{array}$ & $\begin{array}{l}4.68 \\
(.33)\end{array}$ & 1.54 & $\begin{array}{c}2.03 \\
(.2)\end{array}$ & $\begin{array}{l}2.36 \\
(.18)\end{array}$ & $\begin{array}{l}2.25 \\
(.18)\end{array}$ & .22 \\
\hline $\begin{array}{l}\text { Private consumption } \\
\text { growth }\end{array}$ & $\begin{array}{l}2.82 \\
(.49)\end{array}$ & $\begin{array}{l}4.12 \\
(.47)\end{array}$ & $\begin{array}{l}4.34 \\
(.42)\end{array}$ & 1.52 & $\begin{array}{l}1.94 \\
(.26)\end{array}$ & $\begin{array}{l}2.27 \\
(.24)\end{array}$ & $\begin{array}{l}2.27 \\
(.19)\end{array}$ & .33 \\
\hline $\begin{array}{l}\text { Total investment } \\
\text { growth }\end{array}$ & $\begin{array}{c}1.44 \\
(1.68)\end{array}$ & $\begin{array}{l}7.72 \\
(.98)\end{array}$ & $\begin{array}{c}7.91 \\
(1.12)\end{array}$ & 6.47 & $\begin{array}{l}1 \\
(.61)\end{array}$ & $\begin{array}{l}1.91 \\
(.54)\end{array}$ & $\begin{array}{l}2.5 \\
(.72)\end{array}$ & 1.5 \\
\hline $\begin{array}{l}\text { Private investment } \\
\text { growth }\end{array}$ & $\begin{array}{c}1.41 \\
(1.86)\end{array}$ & $\begin{array}{l}9.6 \\
(1.22)\end{array}$ & $\begin{array}{c}7.81 \\
(1.33)\end{array}$ & 6.4 & $\begin{array}{l}1.04 \\
(.75)\end{array}$ & $\begin{array}{l}2.92 \\
(.69)\end{array}$ & $\begin{array}{l}3.15 \\
(.89)\end{array}$ & 2.11 \\
\hline $\begin{array}{l}\text { Business investment } \\
\text { growth }\end{array}$ & $\begin{array}{c}2.23 \\
(1.9)\end{array}$ & $\begin{array}{l}10.88 \\
(1.76)\end{array}$ & $\begin{array}{c}4.98 \\
(2.62)\end{array}$ & 2.75 & $\begin{array}{l}2.97 \\
(1)\end{array}$ & $\begin{array}{c}3.23 \\
(1.18)\end{array}$ & $\begin{array}{l}5.17 \\
(1)\end{array}$ & 2.2 \\
\hline Trade balance & $\begin{array}{c}.71 \\
(1.58)\end{array}$ & $\begin{array}{l}1.85 \\
(1.61)\end{array}$ & $\begin{array}{l}1.56 \\
(1.81)\end{array}$ & .85 & $\begin{array}{c}-.54 \\
(.58)\end{array}$ & $\begin{array}{l}.15 \\
(.64)\end{array}$ & $\begin{array}{c}.95 \\
(.65)\end{array}$ & 1.49 \\
\hline
\end{tabular}

Let us now consider successful versus unsuccessful adjustments as shown in tables 5 and 6 . The comparison between the two is especially striking. In successful episodes total primary spending as a percentage of GDP falls by about $2 \%$ of GDP. Total revenues actually decline by about half of a percentage point of GDP. Thus, successful fiscal adjustments are completely based on spending cuts accompanied by modest tax cuts! On the contrary, in unsuccessful adjustments, total revenue goes up by almost $1.5 \%$ of GDP and primary spending is cut by about $0.8 \%$ of GDP. Once again this comparison points in the direction of spending cuts as the more successful ways of fixing budget problems.

Regarding the composition of spending and revenue, the most striking comparison is given by the transfers item. In successful adjustments, transfers fall by $0.83 \%$ of GDP, whereas in unsuccessful adjustments they grow at about $0.4 \%$, a huge difference between the two episodes of $1.2 \%$ of GDP. This comparison points in a clear direction: it is very difficult, if not impossible, to fix public finances when in trouble without solving the question of automatic increases in entitlements. Regarding the composition of revenues, again as above the most striking difference is on income taxes. Figure 3, once again, gives a striking visual image of these results. 
Table 5

Successful and Unsuccessful Fiscal Adjustments: Size and Composition

\begin{tabular}{|c|c|c|c|c|c|c|c|c|}
\hline & \multicolumn{4}{|c|}{ Successful } & \multicolumn{4}{|c|}{ Unsuccessful } \\
\hline & $\begin{array}{c}{[T-2-} \\
T-1] \\
(1)\end{array}$ & $\begin{array}{c}T \\
(2)\end{array}$ & $\begin{array}{c}{[T+1-} \\
T+2] \\
(3)\end{array}$ & $(3)-(1)$ & $\begin{array}{c}{[T-2-} \\
T-1] \\
(1)\end{array}$ & $\begin{array}{c}T \\
(2)\end{array}$ & $\begin{array}{c}{[T+1-} \\
T+2] \\
\quad(3)\end{array}$ & (3) - (1) \\
\hline Debt & $\begin{array}{c}61.92 \\
(4.32)\end{array}$ & $\begin{array}{c}59.63 \\
(4.50)\end{array}$ & $\begin{array}{c}53.18 \\
(4.16)\end{array}$ & -8.74 & $\begin{array}{l}68.29 \\
(4.32)\end{array}$ & $\begin{array}{l}71.4 \\
(4.53)\end{array}$ & $\begin{array}{c}72.06 \\
(4.48)\end{array}$ & 3.77 \\
\hline Change in debt & $\begin{array}{r}-1.6 \\
(.72)\end{array}$ & $\begin{array}{c}-1.97 \\
(1.14)\end{array}$ & $\begin{array}{r}-3.88 \\
(.34)\end{array}$ & -2.28 & $\begin{array}{l}3.68 \\
(.64)\end{array}$ & $\begin{array}{c}2.29 \\
(.53)\end{array}$ & $\begin{array}{c}2.14 \\
(.43)\end{array}$ & -1.54 \\
\hline Total deficit & $\begin{array}{c}2.5 \\
(1.00)\end{array}$ & $\begin{array}{c}.29 \\
(1.06)\end{array}$ & $\begin{array}{c}.66 \\
(1.09)\end{array}$ & -1.84 & $\begin{array}{l}5.6 \\
(.71)\end{array}$ & $\begin{array}{c}3.77 \\
(.83)\end{array}$ & $\begin{array}{l}3.69 \\
(.85)\end{array}$ & -1.91 \\
\hline Primary deficit & $\begin{array}{l}.8 \\
(.68)\end{array}$ & $\begin{array}{r}-1.2 \\
(.64)\end{array}$ & $\begin{array}{c}-.64 \\
(.69)\end{array}$ & -1.44 & $\begin{array}{l}2.7 \\
(.45)\end{array}$ & $\begin{array}{c}.71 \\
(.51)\end{array}$ & $\begin{array}{c}.57 \\
(.46)\end{array}$ & -2.13 \\
\hline Primary expenditures & $\begin{array}{c}45.78 \\
(1.76)\end{array}$ & $\begin{array}{l}43.67 \\
(1.60)\end{array}$ & $\begin{array}{c}43.83 \\
(1.46)\end{array}$ & -1.95 & $\begin{array}{l}43.46 \\
(1.10)\end{array}$ & $\begin{array}{l}42.68 \\
(1.10)\end{array}$ & $\begin{array}{l}42.74 \\
(1.03)\end{array}$ & -.72 \\
\hline Transfers & $\begin{array}{l}19.86 \\
(1.11)\end{array}$ & $\begin{array}{r}19.07 \\
(.94)\end{array}$ & $\begin{array}{r}19.03 \\
(.89)\end{array}$ & -.83 & $\begin{array}{r}18.38 \\
(.63)\end{array}$ & $\begin{array}{r}18.59 \\
(.64)\end{array}$ & $\begin{array}{r}18.81 \\
(.61)\end{array}$ & .43 \\
\hline Government wage & & & & & & & & \\
\hline expenditures & $\begin{array}{r}12.82 \\
(.69)\end{array}$ & $\begin{array}{l}12.5 \\
(.67)\end{array}$ & $\begin{array}{r}12.3 \\
\quad(.63)\end{array}$ & -.52 & $\begin{array}{c}12.51 \\
(.44)\end{array}$ & $\begin{array}{r}12.3 \\
(.42)\end{array}$ & $\begin{array}{r}12.19 \\
(.40)\end{array}$ & -.32 \\
\hline Government nonwage & & & & & & & & \\
\hline expenditures & $\begin{array}{l}8.73 \\
(.49)\end{array}$ & $\begin{array}{l}8.62 \\
(.47)\end{array}$ & $\begin{array}{l}8.71 \\
(.45)\end{array}$ & -.02 & $\begin{array}{l}7.96 \\
(.30)\end{array}$ & $\begin{array}{l}8.01 \\
(.31)\end{array}$ & $\begin{array}{l}8 \\
(.30)\end{array}$ & .04 \\
\hline Subsidies & $\begin{array}{l}2.29 \\
(.36)\end{array}$ & $\begin{array}{l}2.14 \\
(.35)\end{array}$ & $\begin{array}{l}2.05 \\
(.34)\end{array}$ & -.24 & $\begin{array}{l}2.05 \\
(.14)\end{array}$ & $\begin{array}{l}1.94 \\
(.14)\end{array}$ & $\begin{array}{l}1.93 \\
(.15)\end{array}$ & -.12 \\
\hline Government investment & $\begin{array}{c}2.12 \\
(.38)\end{array}$ & $\begin{array}{l}1.34 \\
(.34)\end{array}$ & $\begin{array}{l}1.74 \\
(.27)\end{array}$ & -.38 & $\begin{array}{c}2.57 \\
(.19)\end{array}$ & $\begin{array}{l}1.85 \\
(.18)\end{array}$ & $\begin{array}{l}1.81 \\
(.16)\end{array}$ & -.76 \\
\hline Total revenue & $\begin{array}{l}44.98 \\
(1.61)\end{array}$ & $\begin{array}{l}44.86 \\
(1.57)\end{array}$ & $\begin{array}{l}44.47 \\
(1.67)\end{array}$ & -.51 & $\begin{array}{l}40.76 \\
(1.04)\end{array}$ & $\begin{array}{l}41.97 \\
(1.04)\end{array}$ & $\begin{array}{l}42.17 \\
(1.03)\end{array}$ & 1.41 \\
\hline Income taxes & $\begin{array}{c}13.69 \\
(1.18)\end{array}$ & $\begin{array}{l}13.43 \\
(1.17)\end{array}$ & $\begin{array}{l}13 \\
(1.16)\end{array}$ & -.69 & $\begin{array}{r}11.02 \\
(.64)\end{array}$ & $\begin{array}{r}11.35 \\
(.65)\end{array}$ & $\begin{array}{r}11.55 \\
(.64)\end{array}$ & .53 \\
\hline Business taxes & $\begin{array}{c}2.77 \\
(.26)\end{array}$ & $\begin{array}{l}3.37 \\
(.31)\end{array}$ & $\begin{array}{c}3.59 \\
(.35)\end{array}$ & .82 & $\begin{array}{c}2.69 \\
(.22)\end{array}$ & $\begin{array}{c}3.08 \\
(.28)\end{array}$ & $\begin{array}{l}3.1 \\
(.31)\end{array}$ & .41 \\
\hline Indirect taxes & $\begin{array}{r}13.77 \\
(.68)\end{array}$ & $\begin{array}{l}13.6 \\
(.61)\end{array}$ & $\begin{array}{r}13.46 \\
(.62)\end{array}$ & -.31 & $\begin{array}{r}12.32 \\
(.33)\end{array}$ & $\begin{array}{r}12.51 \\
(.32)\end{array}$ & $\begin{array}{r}12.63 \\
(.33)\end{array}$ & .31 \\
\hline $\begin{array}{l}\text { Social Security } \\
\text { contributions }\end{array}$ & $\begin{array}{l}10.82 \\
(1.26)\end{array}$ & $\begin{array}{l}10.73 \\
(1.15)\end{array}$ & $\begin{array}{l}10.73 \\
(1.20)\end{array}$ & -.09 & $\begin{array}{r}12.04 \\
(.62)\end{array}$ & $\begin{array}{r}12.25 \\
(.62)\end{array}$ & $\begin{array}{r}12.15 \\
(.64)\end{array}$ & .11 \\
\hline
\end{tabular}

Source: OECD.

Note: Variables are in share of GDP. Total deficit, primary deficit, primary expenditures, transfers, total revenues, and all revenue items are cyclically adjusted variables. Standard deviations of the means are in parentheses. See app. A for the exact definitions of the variables.

\section{Some Regressions}

In this section we present some simple regressions on GDP growth as a function of changes of fiscal policy in the recent past. We should put upfront the fact that causality issues are all over the place here, and we do 
Table 6

Successful and Unsuccessful Fiscal Adjustments and Growth

\begin{tabular}{|c|c|c|c|c|c|c|c|c|}
\hline & \multicolumn{4}{|c|}{ Successful } & \multicolumn{4}{|c|}{ Unsuccessful } \\
\hline & $\begin{array}{c}{[T-2-} \\
T-1] \\
(1)\end{array}$ & $\begin{array}{c}T \\
(2)\end{array}$ & $\begin{array}{c}{[T+1-} \\
T+2] \\
\quad(3)\end{array}$ & (3) $-(1)$ & $\begin{array}{c}{[T-2-} \\
T-1] \\
(1)\end{array}$ & $\begin{array}{l}T \\
(2)\end{array}$ & $\begin{array}{c}{[T+1-} \\
T+2] \\
\quad(3)\end{array}$ & (3) $-(1)$ \\
\hline G7 GDP growth & $\begin{array}{l}.4 \\
(.53)\end{array}$ & $\begin{array}{l}.8 \\
(.46)\end{array}$ & $\begin{array}{c}.85 \\
(.37)\end{array}$ & .45 & $\begin{array}{c}-.18 \\
(.23)\end{array}$ & $\begin{array}{c}-.22 \\
(.22)\end{array}$ & $\begin{array}{c}-.12 \\
(.18)\end{array}$ & .06 \\
\hline GDP growth & $\begin{array}{l}2.99 \\
(.58)\end{array}$ & $\begin{array}{l}3.61 \\
(.5)\end{array}$ & $\begin{array}{l}3.45 \\
(.28)\end{array}$ & .46 & $\begin{array}{l}2.07 \\
(.25)\end{array}$ & $\begin{array}{l}2.56 \\
(.2)\end{array}$ & $\begin{array}{l}2.52 \\
(.21)\end{array}$ & .45 \\
\hline $\begin{array}{l}\text { Private consumption } \\
\text { growth }\end{array}$ & $\begin{array}{l}2.75 \\
(.6)\end{array}$ & $\begin{array}{l}3.74 \\
(.67)\end{array}$ & $\begin{array}{l}3.02 \\
(.3)\end{array}$ & .27 & $\begin{array}{l}2.01 \\
(.26)\end{array}$ & $\begin{array}{l}2.28 \\
(.23)\end{array}$ & $\begin{array}{c}2.42 \\
(.2)\end{array}$ & .41 \\
\hline $\begin{array}{l}\text { Total investment } \\
\text { growth }\end{array}$ & $\begin{array}{c}2.95 \\
(1.37)\end{array}$ & $\begin{array}{c}4.11 \\
(1.54)\end{array}$ & $\begin{array}{c}4.78 \\
(1.24)\end{array}$ & 1.83 & $\begin{array}{l}1.02 \\
(.69)\end{array}$ & $\begin{array}{l}2.55 \\
(.56)\end{array}$ & $\begin{array}{l}3.52 \\
(.73)\end{array}$ & 2.5 \\
\hline $\begin{array}{l}\text { Private investment } \\
\text { growth }\end{array}$ & $\begin{array}{c}3.45 \\
(1.46)\end{array}$ & $\begin{array}{l}5.6 \\
(1.85)\end{array}$ & $\begin{array}{c}5.07 \\
(1.43)\end{array}$ & 1.62 & $\begin{array}{l}1.18 \\
(.81)\end{array}$ & $\begin{array}{l}3.43 \\
(.73)\end{array}$ & $\begin{array}{l}4.23 \\
(.9)\end{array}$ & 3.05 \\
\hline $\begin{array}{l}\text { Business investment } \\
\text { growth }\end{array}$ & $\begin{array}{l}3.2 \\
(1.79)\end{array}$ & $\begin{array}{c}5.46 \\
(2.06)\end{array}$ & $\begin{array}{c}6.06 \\
(1.42)\end{array}$ & 2.86 & $\begin{array}{c}3.23 \\
(1.07)\end{array}$ & $\begin{array}{l}5.17 \\
(.97)\end{array}$ & $\begin{array}{c}5.84 \\
(1.08)\end{array}$ & 2.61 \\
\hline Trade balance & $\begin{array}{l}2.72 \\
(1.1)\end{array}$ & $\begin{array}{l}3.99 \\
(1.03)\end{array}$ & $\begin{array}{c}4.31 \\
(1.51)\end{array}$ & 1.59 & $\begin{array}{c}-.19 \\
(.71)\end{array}$ & $\begin{array}{c}.48 \\
(.77)\end{array}$ & $\begin{array}{l}1.15 \\
(.84)\end{array}$ & 1.34 \\
\hline
\end{tabular}

not claim to have solved them. These regressions should be viewed as correlations, but we find them instructive, and the message they send is on the same line as that emerging from our descriptive analysis above.

Let us begin with fiscal stimuli. In table 7, columns 1-4, we regress real GDP growth in a year of fiscal stimulus on its one-period and two-period lagged values, on the lagged value of the weighted average of the real GDP growth of the G7 countries, on the lagged value of the ratio of public debt to GDP ratio, and on a set of fiscal policy variables measuring the size and the composition of the fiscal stimulus. Columns 5-8 are analogous to the previous four columns except for the left-hand-side variable, now equal to the average of real GDP growth in a year of fiscal stimulus and in the two following ones.

We find that, controlling for initial conditions, a 1-percentage-point higher increase in the current spending to GDP ratio is associated with a 0.75 -percentage-point lower growth. The effect is statistically significant at the $5 \%$ level. Instead, larger increases in spending on capital goods or larger cuts in taxes do not have statistically significant effects on growth (see col. 2). When we try to investigate whether the size of the fiscal stimulus or its composition is relevant for economic growth, we find more evidence in favor of the composition. We measure the size of the fiscal stimulus with 


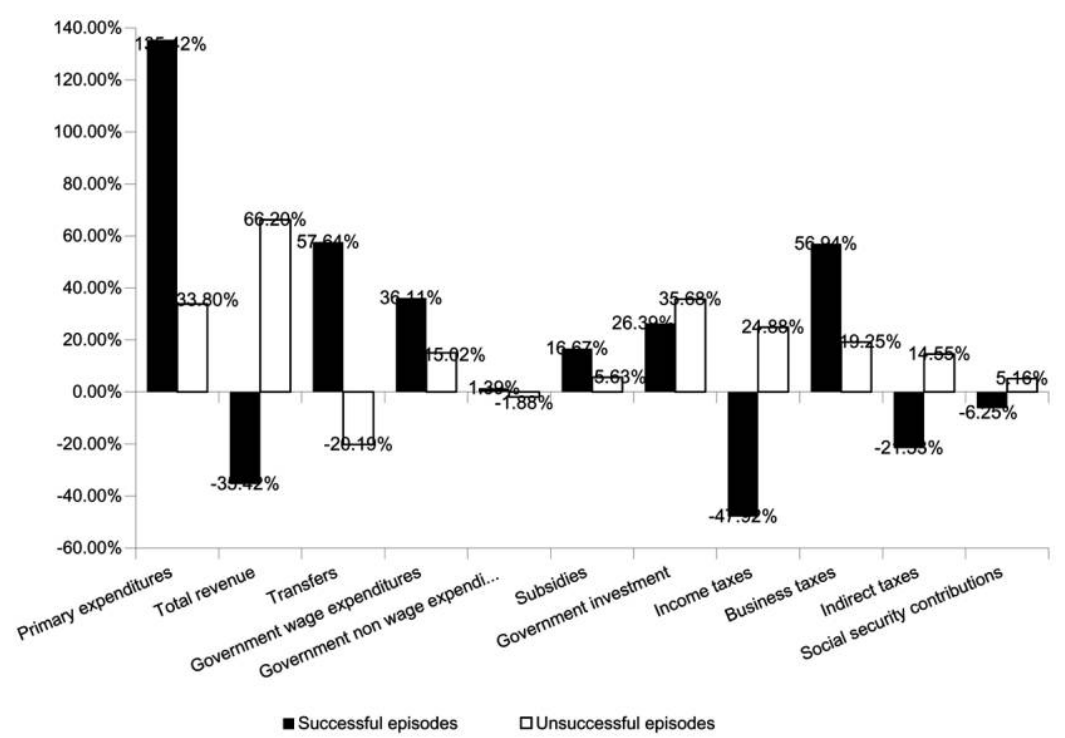

Fig. 3. Contribution of expenditure and revenue items to fiscal adjustments. The figure shows the percentage of the increase (reduction) in the primary deficit (surplus) due to changes in spending and revenue items of the government budget. Positive values indicate that expenditure items decrease and revenue items increase, contributing to an improvement of the primary balance. Negative values indicate that expenditure items increase and revenue items decrease, contributing to a worsening of the primary balance.

the change in the cyclically adjusted primary balance. We measure the composition of fiscal stimuli with two different variables: (i) the ratio between the change in current spending to GDP ratio and the change in the primary balance (cols. 3 and 7) and (ii) the sum of the change in current spending and tax revenue to GDP ratios (cols. 4 and 8) to account for the fact that both current spending increases and tax increases can be negatively associated with growth. Both measures of composition are statistically significant at the $5 \%$ level in all specifications. In column 3, the sign of the ratio between the change in current spending to GDP ratio and the change in the primary balance indicates that the larger the share of the worsening in the primary balance due to spending increases, the lower GDP growth. On average, during years of fiscal stimuli, about $54 \%$ of the deterioration in the primary balance is due to increases in current spending items. A one-standarddeviation increase in this variable (equal to $51 \%$, undoubtedly a very large number) would reduce growth by 1 percentage point. Finally, a larger increase in the primary deficit to GDP ratio is associated with lower growth; however, the effect is statistically significant only in column 3.

Table 8 is very similar to table 7 , but we replace the change in current spending and taxes with their respective components. Consistent with 
Table 7

GDP Growth during and in the Aftermath of a Fiscal Stimulus

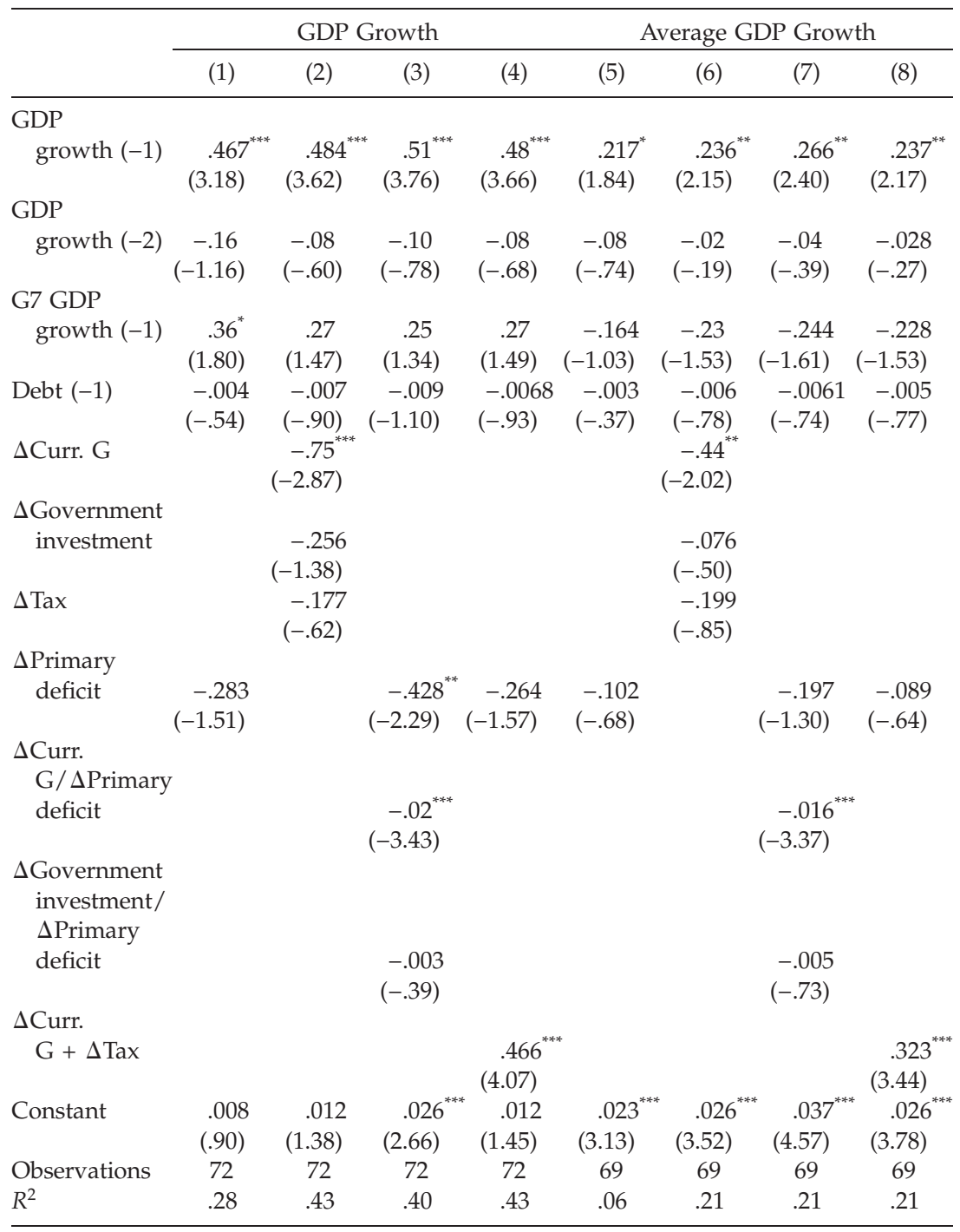

Note: OLS regressions. Dependent variables are the real GDP growth rate during the fiscal stimulus in cols. 1-4 and the average real GDP growth rate during the fiscal stimulus and in the following 2 years in cols. 5-8. $t$-statistics are in parentheses. See app. A for the exact definitions of the variables.

*Statistically significant at the $10 \%$ level.

** Statistically significant at the 5\% level.

*** Statistically significant at the $1 \%$ level. 
Table 8

GDP Growth and the Composition of a Fiscal Stimulus

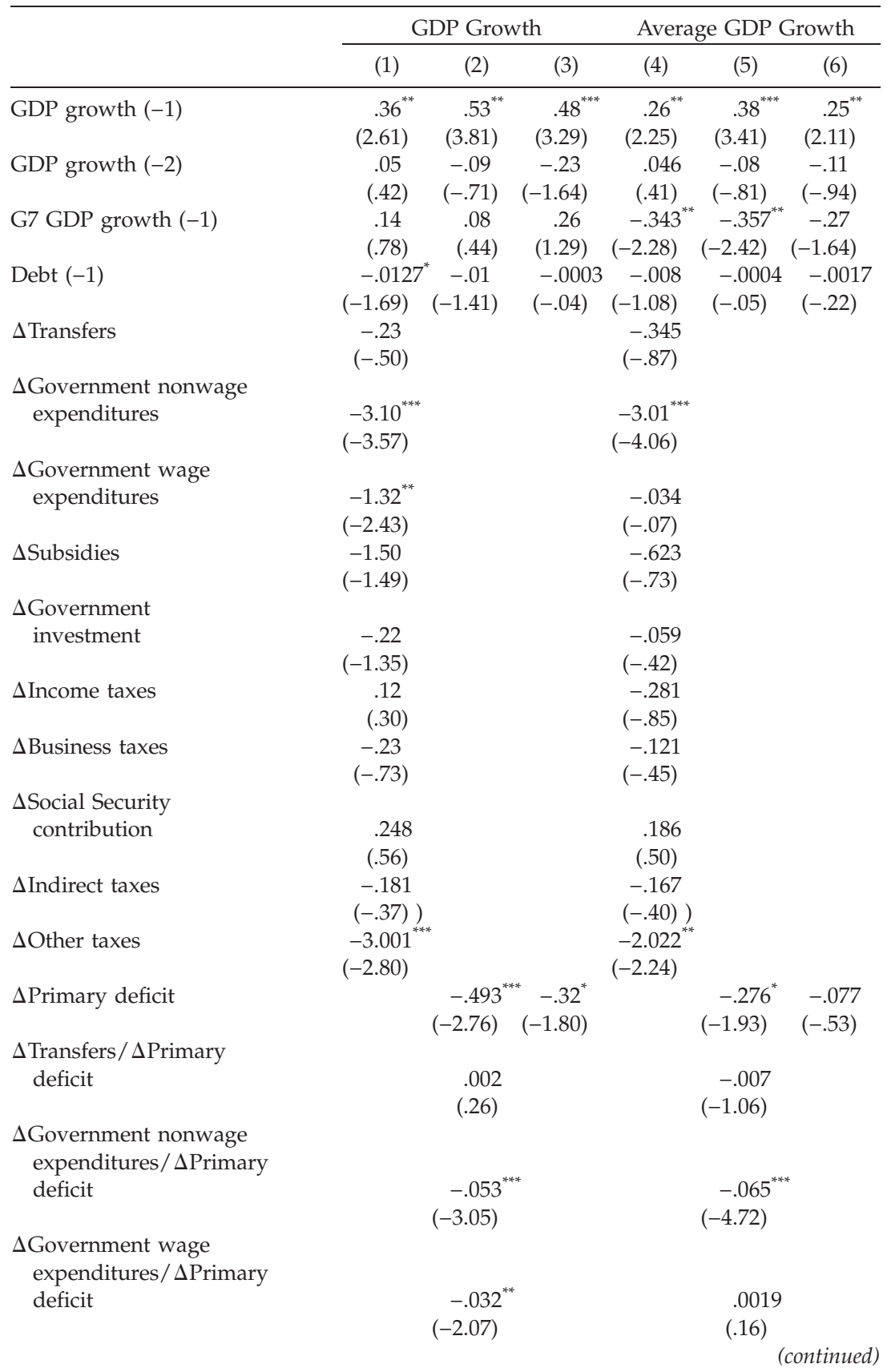


Table 8

Continued

\begin{tabular}{|c|c|c|c|c|c|c|}
\hline & \multicolumn{3}{|c|}{ GDP Growth } & \multicolumn{3}{|c|}{ Average GDP Growth } \\
\hline & $(1)$ & $(2)$ & (3) & (4) & (5) & (6) \\
\hline$\Delta$ Subsidies / $\Delta$ Primary deficit & & $\begin{array}{l}-.062^{* *} \\
(-2.14)\end{array}$ & & & $\begin{array}{r}-.04^{*} \\
(-1.75)\end{array}$ & \\
\hline $\begin{array}{l}\Delta \text { Government investment } \\
\Delta \text { Primary deficit }\end{array}$ & & $\begin{array}{l}-.0016 \\
(-.20)\end{array}$ & & & $\begin{array}{r}-.007 \\
(-1.10)\end{array}$ & \\
\hline$\Delta$ Income taxes / $\Delta$ Primary deficit & & & $\begin{array}{l}.016^{*} \\
(1.93)\end{array}$ & & & $\begin{array}{l}.015^{* *} \\
(2.29)\end{array}$ \\
\hline$\Delta$ Business taxes / $\Delta$ Primary deficit & & & $\begin{array}{l}.029^{* * *} \\
(2.83)\end{array}$ & & & $\begin{array}{r}.017^{*} \\
(1.88)\end{array}$ \\
\hline $\begin{array}{l}\Delta \text { Social Security contributions / } \\
\Delta \text { Primary deficit }\end{array}$ & & & $\begin{array}{c}.01 \\
(.99)\end{array}$ & & & $\begin{array}{r}.008 \\
(1.00)\end{array}$ \\
\hline$\Delta$ Indirect taxes / $\Delta$ Primary deficit & & & $\begin{array}{c}.030^{* *} \\
(2.50)\end{array}$ & & & $\begin{array}{l}.023^{* *} \\
(2.42)\end{array}$ \\
\hline$\Delta$ Other taxes / $\Delta$ Primary deficit & & & $\begin{array}{l}.032^{* *} \\
(2.48)\end{array}$ & & & $\begin{array}{c}.014 \\
(1.34)\end{array}$ \\
\hline Constant & $\begin{array}{l}.027^{* * *} \\
(3.12)\end{array}$ & $\begin{array}{l}.035^{* * *} \\
(3.65)\end{array}$ & $\begin{array}{l}.006 \\
(.70)\end{array}$ & $\begin{array}{l}.035^{* * *} \\
(4.72)\end{array}$ & $\begin{array}{l}.041^{* * *} \\
(5.28)\end{array}$ & $\begin{array}{l}.019^{* * *} \\
(2.73)\end{array}$ \\
\hline Observations & 67 & 69 & 70 & 64 & 66 & 67 \\
\hline$R^{2}$ & .63 & .51 & .43 & .47 & .39 & .21 \\
\hline
\end{tabular}

Note: OLS regressions. Dependent variables are the real GDP growth rate during the fiscal stimulus in cols. 1-3 and the average real GDP growth rate during the fiscal stimulus and in the following 2 years in cols. 4-6. $t$-statistics are in parentheses. See app. A for the exact definitions of the variables.

* Statistically significant at the $10 \%$ level.

** Statistically significant at the 5\% level.

${ }^{* * *}$ Statistically significant at the $1 \%$ level.

the evidence in table 7, our regressions show that fiscal stimuli more heavily based on increases in current spending items (government wage and nonwage components, subsidies) are associated with lower growth, whereas fiscal stimulus packages based on cuts in income and business and indirect taxes are more likely to be expansionary.

When we turn to the sample of fiscal adjustments (tables 9 and 10), our results still point in the same direction: namely, the composition of the fiscal adjustment, more than its size, matters for growth, and fiscal adjustments associated with higher GDP growth are those in which a larger share of the reduction of the primary deficit-to-GDP ratio is due to cuts in current spending, to the government wage and nonwage components, and to subsidies. All this evidence is consistent with the previous literature on fiscal stabilizations and is robust if we introduce among the regressors the change in the short-term interest rate as a control for the 
Table 9

GDP Growth during and in the Aftermath of a Fiscal Adjustment

\begin{tabular}{|c|c|c|c|c|c|c|c|c|}
\hline & \multicolumn{4}{|c|}{ GDP Growth } & \multicolumn{4}{|c|}{ Average GDP Growth } \\
\hline & (1) & (2) & (3) & (4) & (5) & (6) & (7) & (8) \\
\hline \multicolumn{9}{|l|}{ GDP } \\
\hline growth $(-1)$ & $\begin{array}{l}.296^{* * *} \\
(2.99)\end{array}$ & $\begin{array}{c}.288^{* * *} \\
(3.12)\end{array}$ & $\begin{array}{l}.269^{* * *} \\
(3.04)\end{array}$ & $\begin{array}{c}.30^{* * * *} \\
(3.29)\end{array}$ & $\begin{array}{l}.198^{* *} \\
(2.41)\end{array}$ & $\begin{array}{l}.197^{* *} \\
(2.56)\end{array}$ & $\begin{array}{l}.182^{* *} \\
(2.48)\end{array}$ & $\begin{array}{c}.202^{* * *} \\
(2.66)\end{array}$ \\
\hline \multicolumn{9}{|c|}{ 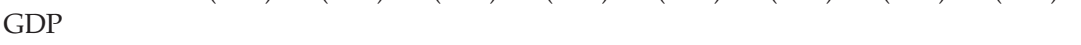 } \\
\hline growth (-2) & $\begin{array}{l}-.0013 \\
(-.01)\end{array}$ & $\begin{array}{l}.08 \\
(.98)\end{array}$ & $\begin{array}{r}.123 \\
(1.50)\end{array}$ & $\begin{array}{c}.07 \\
(.86)\end{array}$ & $\begin{array}{l}-.059 \\
(-.80)\end{array}$ & $\begin{array}{l}.01 \\
(.14)\end{array}$ & $\begin{array}{l}.045 \\
(.66)\end{array}$ & $\begin{array}{l}.007 \\
(.10)\end{array}$ \\
\hline \multicolumn{9}{|l|}{ G7 GDP } \\
\hline growth $(-1)$ & $\begin{array}{l}.116 \\
(.76)\end{array}$ & $\begin{array}{l}.038 \\
(.27)\end{array}$ & $\begin{array}{l}.018 \\
(.13)\end{array}$ & $\begin{array}{l}.025 \\
(.18)\end{array}$ & $\begin{array}{l}.005 \\
(.04)\end{array}$ & $\begin{array}{l}-.068 \\
(-.58)\end{array}$ & $\begin{array}{l}-.08 \\
(-.72)\end{array}$ & $\begin{array}{l}-.07 \\
(-.63)\end{array}$ \\
\hline Debt $(-1)$ & $\begin{array}{c}-.011^{*} \\
(-1.84)\end{array}$ & $\begin{array}{c}-.006 \\
(-1.11)\end{array}$ & $\begin{array}{r}-.007 \\
(-1.33)\end{array}$ & $\begin{array}{r}-.009 \\
(-1.54)\end{array}$ & $\begin{array}{r}-.008 \\
(-1.42)\end{array}$ & $\begin{array}{c}-.006 \\
(-1.05)\end{array}$ & $\begin{array}{r}-.006 \\
(-1.22)\end{array}$ & $\begin{array}{r}-.006 \\
(-1.20)\end{array}$ \\
\hline$\Delta$ Curr. G & & $\begin{array}{l}-.433^{* *} \\
(-2.55)\end{array}$ & & & & $\begin{array}{c}-.296^{* *} \\
(-2.10)\end{array}$ & & \\
\hline $\begin{array}{c}\Delta \text { Government } \\
\text { investment }\end{array}$ & & $\begin{array}{l}.082 \\
(.60)\end{array}$ & & & & $\begin{array}{c}.046 \\
(.41)\end{array}$ & & \\
\hline$\Delta \operatorname{Tax}$ & & $\begin{array}{c}-.22 \\
(-1.09)\end{array}$ & & & & $\begin{array}{c}-.26 \\
(-1.56)\end{array}$ & & \\
\hline $\begin{array}{l}\Delta \text { Primary } \\
\text { deficit }\end{array}$ & $\begin{array}{l}-.044 \\
(-.33)\end{array}$ & & $\begin{array}{l}-.023 \\
(-.19)\end{array}$ & $\begin{array}{l}.016 \\
(.13)\end{array}$ & $\begin{array}{l}-.027 \\
(-.24)\end{array}$ & & $\begin{array}{l}.006 \\
(.06)\end{array}$ & $\begin{array}{l}.024 \\
(.23)\end{array}$ \\
\hline $\begin{array}{l}\Delta \text { Curr. G/ } \\
\Delta \text { Primary } \\
\text { deficit }\end{array}$ & & & $\begin{array}{l}.017^{* * *} \\
(4.70)\end{array}$ & & & & $\begin{array}{l}.015^{* * *} \\
(4.81)^{-}\end{array}$ & \\
\hline $\begin{array}{c}\Delta \text { Government } \\
\text { investment/ } \\
\Delta \text { Primary } \\
\text { deficit }\end{array}$ & & & $\begin{array}{l}.0013 \\
(.28)\end{array}$ & & & & $\begin{array}{l}.004 \\
(.96)\end{array}$ & \\
\hline $\begin{array}{l}\Delta \text { Curr. } \\
\quad \text { G }+\Delta \operatorname{Tax}\end{array}$ & & & & $\begin{array}{c}.34^{* * *} \\
(3.80)\end{array}$ & & & & $\begin{array}{l}.284^{* * *} \\
(3.84)\end{array}$ \\
\hline Constant & $\begin{array}{l}.027^{* * *} \\
(3.85)\end{array}$ & $\begin{array}{c}.024^{* * *} \\
(3.44)\end{array}$ & $\begin{array}{l}.019^{* * *} \\
(2.97)\end{array}$ & $\begin{array}{c}.027^{* * *} \\
(4.23)\end{array}$ & $\begin{array}{c}.029^{* * *} \\
(4.90)\end{array}$ & $\begin{array}{c}.029^{* * * *} \\
(4.87)\end{array}$ & $\begin{array}{l}.024^{* * * *} \\
(4.28)\end{array}$ & $\begin{array}{l}.03^{* * *} \\
(5.41)\end{array}$ \\
\hline Observations & 88 & 88 & 88 & 88 & 83 & 83 & 83 & 83 \\
\hline$R^{2}$ & .22 & .35 & .40 & .34 & .12 & .27 & .34 & .27 \\
\hline
\end{tabular}

Note: OLS regressions. Dependent variables are the real GDP growth rate during the fiscal adjustment in cols. 1-4 and the average real GDP growth rate during the fiscal adjustment and in the following 2 years in cols. 5-8. $t$-statistics are in parentheses. See app. A for the exact definitions of the variables.

*Statistically significant at the $10 \%$ level.

${ }^{* *}$ Statistically significant at the $5 \%$ level.

${ }^{* * *}$ Statistically significant at the $1 \%$ level. 
Table 10

GDP Growth and the Composition of a Fiscal Adjustment

\begin{tabular}{|c|c|c|c|c|c|c|}
\hline \multirow{3}{*}{ GDP growth (-1) } & \multicolumn{3}{|c|}{ GDP Growth } & \multicolumn{3}{|c|}{ Average GDP Growth } \\
\hline & (1) & (2) & (3) & (4) & (5) & (6) \\
\hline & $\begin{array}{l}.208^{* *} \\
(2.11)\end{array}$ & $\begin{array}{l}.26^{* * *} \\
(2.99)\end{array}$ & $\begin{array}{l}.276^{* *} \\
(2.54)\end{array}$ & $\begin{aligned} .127 \\
(1.58)\end{aligned}$ & $\begin{array}{l}.187^{* *} \\
(2.56)\end{array}$ & $\begin{array}{l}.155^{*} \\
(1.80)\end{array}$ \\
\hline GDP growth $(-2)$ & $\begin{array}{r}.112 \\
(1.26)\end{array}$ & $\begin{array}{c}.13 \\
(1.59)\end{array}$ & $\begin{array}{l}.072 \\
(.74)\end{array}$ & $\begin{array}{r}.079 \\
(1.09)\end{array}$ & $\begin{array}{l}.06 \\
(.88)\end{array}$ & $\begin{array}{l}.036 \\
(.47)\end{array}$ \\
\hline G7 GDP growth $(-1)$ & $\begin{array}{l}.068 \\
(.44)\end{array}$ & $\begin{array}{l}-.05 \\
(-.37)\end{array}$ & $\begin{array}{l}.108 \\
(.61)\end{array}$ & $\begin{array}{l}-.048 \\
(-.39)\end{array}$ & $\begin{array}{c}-.15 \\
(-1.33)\end{array}$ & $\begin{array}{l}-.04 \\
(-.30)\end{array}$ \\
\hline Debt $(-1)$ & $\begin{array}{l}-.013^{* *} \\
(-2.08)\end{array}$ & $\begin{array}{c}-.010^{*} \\
(-1.74)\end{array}$ & $\begin{array}{c}-.013^{*} \\
(-1.95)\end{array}$ & $\begin{array}{l}-.014^{* *} \\
(-2.43)\end{array}$ & $\begin{array}{c}-.008^{*} \\
(-1.69)\end{array}$ & $\begin{array}{l}-.012^{*} \\
(-1.99)\end{array}$ \\
\hline$\Delta$ Transfers & $\begin{array}{l}-.057 \\
(-.20)\end{array}$ & & & $\begin{array}{c}-.30 \\
(-1.27)\end{array}$ & & \\
\hline $\begin{array}{l}\Delta \text { Government nonwage } \\
\text { expenditures }\end{array}$ & $\begin{array}{l}-1.53^{* *} \\
(-2.59)\end{array}$ & & & $\begin{array}{l}-.46 \\
(-.94)\end{array}$ & & \\
\hline $\begin{array}{l}\Delta \text { Government wage } \\
\text { expenditures }\end{array}$ & $\begin{array}{l}-1.18^{* * *} \\
(-2.66)\end{array}$ & & & $\begin{array}{l}-1.05^{* * *} \\
(-2.85)\end{array}$ & & \\
\hline$\Delta$ Subsidies & $\begin{array}{l}-1.98^{* *} \\
(-2.61)\end{array}$ & & & $\begin{array}{l}-1.84^{* * *} \\
(-2.93)\end{array}$ & & \\
\hline $\begin{array}{l}\Delta \text { Government } \\
\text { investment }\end{array}$ & $\begin{array}{c}.044 \\
(.32)\end{array}$ & & & $\begin{array}{l}-.002 \\
(-.02)\end{array}$ & & \\
\hline$\Delta$ Income taxes & $\begin{array}{l}-.016 \\
(-.06)\end{array}$ & & & $\begin{array}{c}.04 \\
(.18)\end{array}$ & & \\
\hline$\Delta$ Business taxes & $\begin{array}{r}-.57^{*} \\
(-1.92)\end{array}$ & & & $\begin{array}{l}-.79^{* * *} \\
(-3.19)\end{array}$ & & \\
\hline $\begin{array}{l}\Delta \text { Social Security } \\
\text { contributions }\end{array}$ & $\begin{array}{l}-.04 \\
(-.10)\end{array}$ & & & $\begin{array}{l}-.24 \\
(-.64)\end{array}$ & & \\
\hline$\Delta$ Indirect taxes & $\begin{array}{l}-.19 \\
(-.43)\end{array}$ & & & $\begin{array}{c}-.37 \\
(-1.03)\end{array}$ & & \\
\hline$\Delta$ Other taxes & $\begin{array}{l}-.27 \\
(-.50)\end{array}$ & & & $\begin{array}{l}.106 \\
(.24)\end{array}$ & & \\
\hline$\Delta$ Primary deficit & & $\begin{array}{l}-.084 \\
(-.70)\end{array}$ & $\begin{array}{l}.051 \\
(.35)\end{array}$ & & $\begin{array}{l}-.022 \\
(-.22)\end{array}$ & $\begin{array}{l}.077 \\
(.67)\end{array}$ \\
\hline$\Delta$ Transfers / $\Delta$ Primary deficit & & $\begin{array}{l}.006 \\
(1.01)\end{array}$ & & & $\begin{array}{l}.009^{*} \\
(1.93)\end{array}$ & \\
\hline $\begin{array}{l}\Delta \text { Government nonwage } \\
\text { expenditures / } \Delta \text { Primary } \\
\text { deficit }\end{array}$ & & $\begin{array}{l}.025^{* *} \\
(2.23)\end{array}$ & & & $\begin{array}{l}.005 \\
(.56)\end{array}$ & \\
\hline $\begin{array}{l}\Delta \text { Government wage } \\
\text { expenditures / } \Delta \text { Primary } \\
\text { deficit }\end{array}$ & & $\begin{array}{l}.026^{* * *} \\
(3.16)\end{array}$ & & & $\begin{array}{l}.022^{* * *} \\
(3.04)\end{array}$ & \\
\hline$\Delta$ Subsidies / $\Delta$ Primary deficit & & $\begin{array}{l}.043^{* * *} \\
(2.69)^{2}\end{array}$ & & & $\begin{array}{c}.036^{* * *} \\
(2.66)\end{array}$ & \\
\hline
\end{tabular}


Table 10

Continued

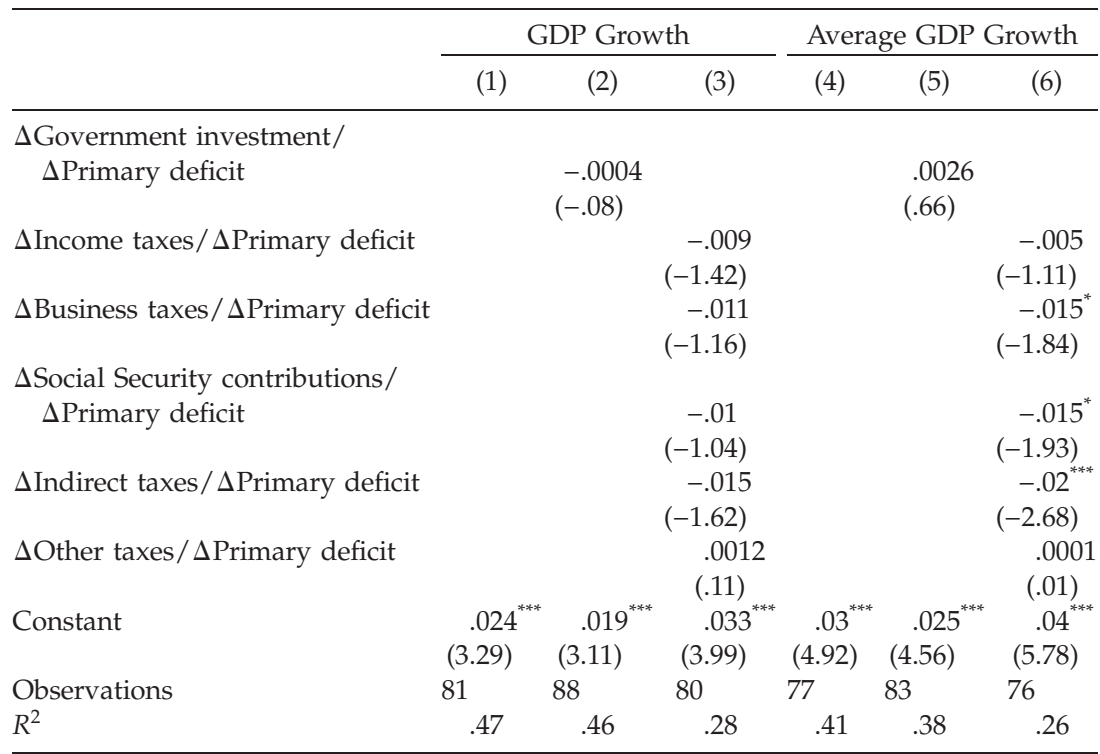

Note: OLS regressions. Dependent variables are the real GDP growth rate during the fiscal adjustment in cols. 1-3 and the average real GDP growth rate during the fiscal adjustment and in the following 2 years in cols. 4-6. $t$-statistics are in parentheses. See app. A for the exact definitions of the variables.

* Statistically significant at the $10 \%$ level.

${ }^{* *}$ Statistically significant at the 5\% level.

${ }^{* * *}$ Statistically significant at the $1 \%$ level.

stance of monetary policy or the rate of change of the nominal exchange rate to control for exchange rate devaluations that can occur at the same time of large changes in the fiscal stance (results are not shown but are available on request).

Finally, we have estimated the same specifications as in tables 7 and 9, columns 1,2, and 4, for the entire sample of OECD data that, hence, includes episodes of fiscal adjustments, stimuli, and years in which the cyclically adjusted primary balance changes between $-1.5 \%$ and $1.5 \%$. We have also checked whether there are nonlinearities associated with times of large fiscal adjustments and stimuli. Table 11 shows the results. ${ }^{10}$ Results are in line with the evidence shown so far: we find that larger reductions in current spending and in taxation are associated with higher GDP growth, whereas changes in capital spending do not show any significant effect on growth. Moreover, the specifications in columns 4-9 do not support any evidence of nonlinearities in episodes of fiscal adjustments or stimuli. Both the coefficients of the dummy variables Tight and Loose 


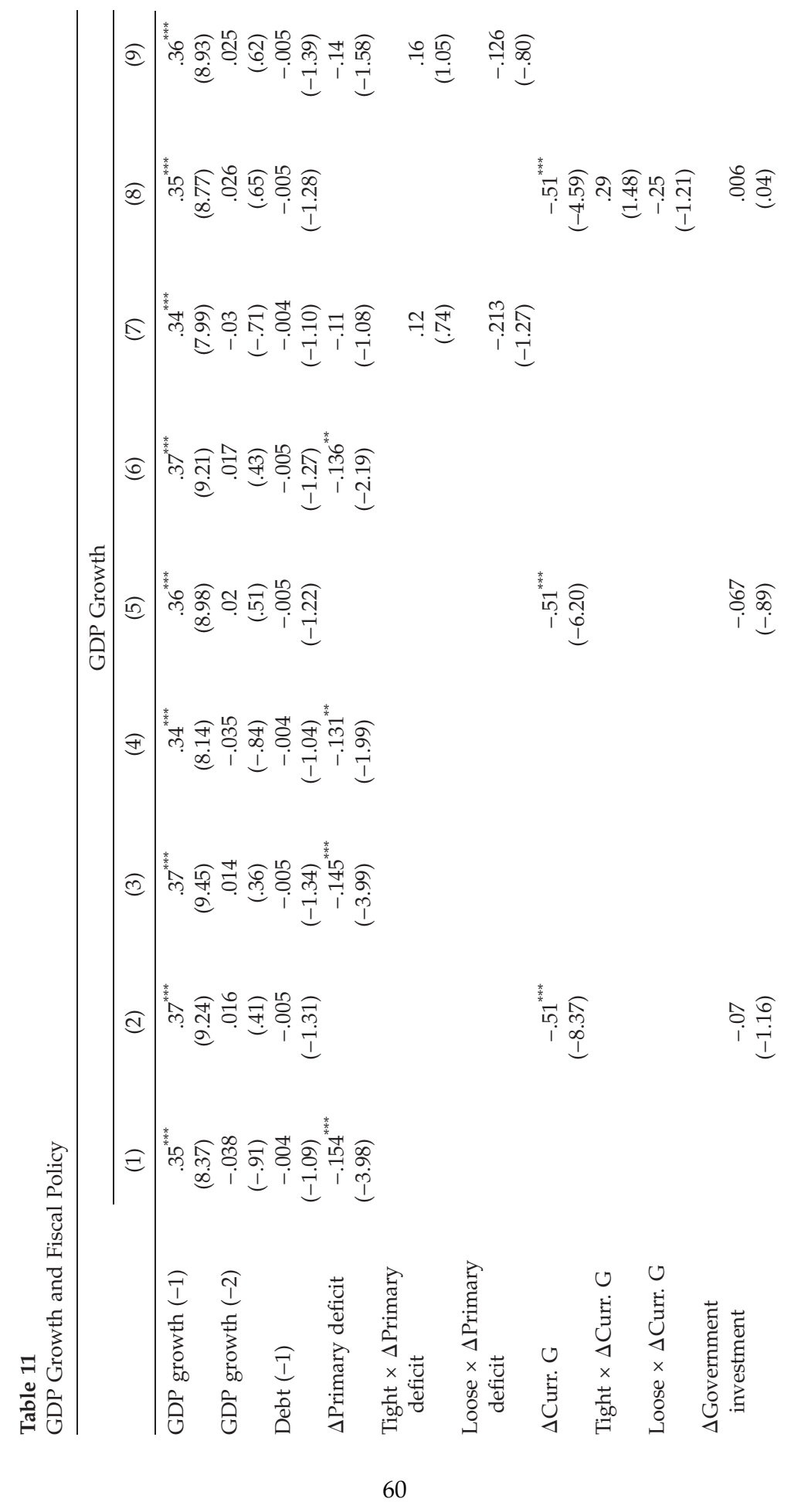




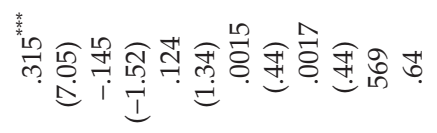

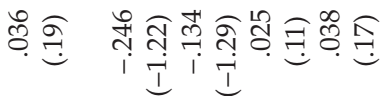

*군 
and the coefficients between the interaction terms of these variables and the fiscal policy indicators are not statistically significant. As suggested by Alesina et al. (2002), there seems to be nothing special around such episodes that can explain the behavior of growth relatively to normal times.

\section{Conclusions}

Rather than reviewing our results again, it is worth elaborating, or perhaps speculating on, the current and future fiscal stance in the United States. As we well know, a very large portion of the current astronomical $12 \%$ of GDP deficit is the result of bailouts of various types of the financial sector. This is an issue on which this paper has nothing to say. But part of the deficit is the result of the stimulus package that was passed to lift the economy out of the recession. About two-thirds of this fiscal package is constituted by increases in spending, including public investment, transfers, and government consumption. According to our results, fiscal stimuli based on tax cuts are much more likely to be growth enhancing than those on the spending side. Needless to say, when a single episode is considered, many other factors jump to mind, factors that are difficult to capture in multicountry regressions. For instance, American families were saving too little before the crisis. An income tax cut might have just simply been saved and might not have had a big impact on aggregate consumption. However, more saving might have reinforced the financial sector; think of the credit card crisis, for instance. In addition, one could have thought of tax cuts that stimulate investment. The benefit of infrastructure projects that have "long and variable lags" is much more questionable.

After the "perfect storm" of this current crisis, the United States will emerge with an unprecedented (for peacetime) increase in government debt. As we argued in the introduction, it is unlikely that these deficits and debt will disappear simply because growth will resume at a very rapid pace very soon. Primary suppressions would be needed since interest rates cannot go other than up from the close to zero actual levels. The analysis of the present paper suggests that unless primary spending is cut, it is difficult to achieve fiscal stability because spending may rise faster than tax revenue. But what can be cut? It is hoped that improvements in the peace process in Afghanistan and Iraq might allow a reduction of military expenditure, but given the instability in the region, one cannot count on that for sure. Health care reforms seem to imply large 
increases in spending, the retirement of the baby boomers is not too far, and in the pressing time of the crisis the issue of Social Security has been in the background but has not disappeared. A relatively high unemployment rate for a couple more years will require spending on subsidies. The budget outlook looks rather grim on the spending side. The Congressional Budget Office predicts a deficit of $7 \%$ of GDP up to 2020 . This is not a rosy scenario.

\section{Appendix A}

\section{Data}

Debt. Government gross debt as a share of GDP.

Total deficit. Cyclically adjusted total deficit as a share of GDP: = primary deficit + (interest expenses on government debt/GDP).

Primary deficit. Cyclically adjusted primary deficit as a share of GDP: = primary expenses - total revenue.

Primary expenses. Cyclically adjusted primary expenditure as a share of GDP: $=$ transfers $+[$ (government wage expenditures + government nonwage expenditures + subsidies + government investment)/GDP].

Curr. G. Cyclically adjusted current expenditure as a share of GDP: $=$ transfers + [ (government wage expenditures + government nonwage expenditures + subsidies)/GDP].

Transfers. Cyclically adjusted transfers as a share of GDP.

Government wage expenditures. Government wage bill expenditures.

Government nonwage expenditures. Government nonwage bill expenditures.

Subsidies. Subsidies to firms.

Government investment. Gross government consumption on fixed capital.

Total revenue $=\operatorname{tax}$. Cyclically adjusted total revenue as a share of GDP: $=$ income taxes + business taxes + indirect taxes + Social Security contributions + (other taxes/GDP).

Income taxes. Cyclically adjusted income taxes as a share of GDP: = cyclically adjusted direct taxes on household as a share of GDP.

Business taxes. Cyclically adjusted business taxes as a share of GDP: = cyclically adjusted direct taxes on businesses as a share of GDP.

Indirect taxes. Cyclically adjusted indirect taxes as a share of GDP.

Social Security contributions. Cyclically adjusted Social Security contributions paid by employers and employees as a share of GDP.

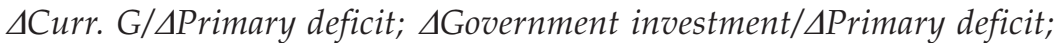
$\Delta$ Spending item/APrimary deficit. An increase in these variables means that 
a larger share of the increase (reduction) of the primary deficit is obtained by increasing (cutting) current spending/government investment/ spending item.

$\Delta$ Tax revenue item/4Primary deficit. An increase in these variables means that a larger share of the increase (reduction) of the primary deficit is obtained by cutting (increasing) a revenue item of the government budget.

$\Delta C u r r . G+\Delta T a x$. This is actually equal to the negative of this variable. If both taxes and spending are cut during the episode of loose or tight fiscal policy, the variable has the "highest positive" value. If, instead, both spending and taxes increase, the variable has the "highest negative value."

G7 GDP growth. Average growth rate of real GDP (with GDP weights) of the seven major industrial countries.

GDP growth. Growth rate of real per capita GDP.

Trade balance. Trade balance as a share of GDP: $=$ (exports of goods and services - imports of goods and services)/GDP.

\section{Appendix B}

Table B1

Episodes of Fiscal Stimuli and Adjustments

\begin{tabular}{ll}
\hline Country & \multicolumn{1}{c}{ Years of Episodes } \\
& \multicolumn{1}{c}{ A. Fiscal Stimuli } \\
\cline { 2 - 2 } Australia & \multicolumn{1}{c}{1990,1991} \\
Austria & 1975,2004 \\
Belgium & $1975,1981,2005$ \\
Canada & $1975,1982,1991,2001$ \\
Denmark & $1974,1975,1980,1981,1982$ \\
Finland & $1978,1982,1983,1987,1990,1991,1992,2001,2003$ \\
France & $1975,1981,1992,1993,2002$ \\
Germany & 1995,2001 \\
Greece & $1981,1985,1989,1995,2001$ \\
Ireland & $1974,1975,1978,2001,2007$ \\
Italy & $1972,1975,1981,2001$ \\
Japan & $1975,1993,1998,2005,2007$ \\
Netherlands & $1975,1980,1995,2001,2002$ \\
New Zealand & 1988 \\
Norway & $1974,1976,1977,1986,1987,1991,1998,2002,2007$ \\
Portugal & $1978,1985,1993,2005$ \\
Spain & $1981,1982,1993$ \\
Sweden & $1974,1977,1979,1980,1991,1992,2001,2002$ \\
United Kingdom & $1971,1972,1973,1990,1991,1992,2001,2002,2003$ \\
United States & 2002 \\
&
\end{tabular}

(continued) 
Table B1

Continued

\begin{tabular}{ll}
\hline Country & \multicolumn{1}{c}{ Years of Episodes } \\
\hline & \multicolumn{1}{c}{ B. Fiscal Adjustments } \\
\cline { 2 - 2 } Australia & 1987,1988 \\
Austria & $1984,1996,1997,2005$ \\
Belgium & $1982,1984,1987,2006$ \\
Canada & $1981,1986,1987,1995,1996,1997$ \\
Denmark & $1983,1984,1985,1986,2005$ \\
Finland & $1973,1976,1981,1984,1988,1994,1996,1998,2000$ \\
France & 1979,1996 \\
Germany & 1996,2000 \\
Greece & $1976,1986,1991,1994,1996,2005,2006$ \\
Ireland & $1976,1984,1987,1988,1989,2000$ \\
Italy & $1976,1980,1982,1990,1991,1992,1997,2007$ \\
Japan & $1984,1999,2001,2006$ \\
Netherlands & $1972,1973,1983,1988,1991,1993,1996$ \\
New Zealand & $1987,1989,1993,1994,2000$ \\
Norway & $1979,1980,1983,1989,1996,2000,2004,2005$ \\
Portugal & $1982,1983,1986,1988,1992,1995,2002,2006$ \\
Spain & $1986,1987,1994,1996$ \\
Sweden & $1981,1983,1984,1986,1987,1994,1996,1997,2004$ \\
United Kingdom & $1977,1982,1988,1996,1997,1998,2000$ \\
\hline & \\
\hline & \\
\hline
\end{tabular}

\section{Table B2}

Episodes of Expansionary Fiscal Stimuli, Expansionary Fiscal Adjustments, and Successful Fiscal Adjustments

\begin{tabular}{ll}
\hline Country & \multicolumn{1}{c}{ Years of Episodes } \\
\hline & \multicolumn{1}{c}{ A. Expansionary Fiscal Stimuli } \\
\cline { 2 - 2 } Canada & 2001 \\
Finland & 1978,1987 \\
Greece & 2001 \\
Ireland & $1974,1975,1978,2001,2007$ \\
Italy & 1972 \\
Japan & 1975 \\
Netherlands & 1995 \\
Norway & $1974,1991,2007$ \\
Portugal & 1978,1985 \\
United Kingdom & $2001,2002,2003$ \\
\cline { 2 - 2 } & B. Expansionary Fiscal Adjustments \\
\cline { 2 - 2 } Finland & $1973,1996,1998,2000$ \\
Greece & $1976,2005,2006$ \\
Ireland & $1976,1987,1988,1989,2000$ \\
Netherlands & 1996 \\
New Zealand & $1993,1994,2000$ \\
Norway & $1979,1980,1983,1996$ \\
Portugal & $1986,1988,1995$ \\
Spain & 1986,1987 \\
Sweden & 2004
\end{tabular}


Table B2

Continued

\begin{tabular}{ll}
\hline Country & \multicolumn{1}{c}{ Years of Episodes } \\
\hline & C. Successful Fiscal Adjustments \\
\cline { 2 - 2 } Austria & 2005 \\
Denmark & 2005 \\
Finland & 1998 \\
Ireland & 2000 \\
Italy & 1982 \\
Netherlands & $1972,1973,1993,1996$ \\
New Zealand & 1993,1994 \\
Norway & $1979,1980,1989,1996$ \\
Sweden & $1986,1987,2004$ \\
United Kingdom & $1977,1988,2000$ \\
\hline
\end{tabular}

\section{Endnotes}

Prepared for the 2009 Tax Policy and the Economy conference. We thank Jeffrey Brown, Roberto Perotti, Matthew Shapiro, and other conference participants for useful comments and discussions.

1. See Alesina (2000) for a discussion of the budget surplus in the 1990s in the United States.

2. For models that highlight this channel, see Bertola and Drazen (1993) and Sutherland (1997).

3. To calculate the measure of the fiscal variable in period $t$ as if the unemployment rate were equal to the one in $t-1$, we follow the procedure in Alesina and Perotti (1995). Specifically, for each country in the sample, we regress the fiscal policy variable as a share of GDP on a time trend and on the unemployment rate. Then, using the coefficients and the residuals from the estimated regressions, we predict what the value of the fiscal variable as a share of GDP in period $t$ would have been if the unemployment rate were the same as in the previous year.

4. More on this is available from the authors.

5. See app. A for a detailed definition of each variable used in the empirical analysis.

6. If an episode of tight fiscal policy takes place in 2005, the cumulative change of the debt-to-GDP ratio is computed over a 2-year horizon so as not to lose too many observations at the end of the sample. If the episode occurs after 2005, we cannot determine whether it is a successful or an unsuccessful one.

7. More details on this sensitivity analysis are available from the authors.

8. The Denmark fiscal contraction is the only episode lasting 4 years. We have included the values of the variables in 1986 in the column $[T+1, T+2]$. We checked and confirm that the qualitative nature of the results does not change if the period [T] includes all the years of a tight/expansionary episode of fiscal policy and the period $[T+1, T+2]$ is the 2-year period following the last year of an episode.

9. See also Alesina et al. (2002) for related work on the effect of fiscal policy on investment.

10. Regressions in table 11 include country and year dummies among the right-hand-side variables.

\section{References}

Aghion, Philippe, Alberto Alesina, and Francesco Trebbi. 2004. "Endogenous Political Institutions." Quarterly Journal of Economics 119:565-612. 
$\rightarrow$ Alesina, Alberto. 2000. "The Political Economy of the Budget Surplus in the US." Journal of Economic Perspectives 14 (Summer): 3-19.

$\rightarrow$ Alesina, Alberto, and Silvia Ardagna. 1998. "Tales of Fiscal Adjustments." Economic Policy 13 (October): 489-545.

$\rightarrow$ Alesina, Alberto, Silvia Ardagna, Roberto Perotti, and Fabio Schiantarelli. 2002. "Fiscal Policy, Profits, and Investment." American Economic Review 92 (June): 571-89.

$\rightarrow$ Alesina, Alberto, and Allan Drazen. 1991. "Why Are Stabilizations Delayed?" American Economic Review 81:1170-88.

Alesina, Alberto, and Edward Glaeser. 2004. Fighting Poverty in the US and Europe: A World of Difference. Oxford: Oxford University Press.

Alesina, Alberto, and Roberto Perotti. 1995. "Fiscal Expansions and Adjustments in OECD Countries." Economic Policy, no. 21:207-47.

$\rightarrow$ _ 1997. "The Welfare State and Competitiveness." American Economic Review 87:921-39.

$\rightarrow$ Alesina, Alberto, Roberto Perotti, and José Tavares. 1998. “The Political Economy of Fiscal Adjustments." Brookings Papers on Economic Activity, no. 1:197-248.

$\rightarrow$ Ardagna, Silvia. 2004. "Fiscal Stabilizations: When Do They Work and Why?" European Economic Review 48 (October): 1047-74.

$\rightarrow$ Bertola, Giuseppe, and Allan Drazen. 1993. "Trigger Points and Budget Cuts: Explaining the Effects of Fiscal Austerity." American Economic Review 83, no. 1:11-26.

$\rightarrow$ Blanchard, Olivier J. 1990. "Comment on Giavazzi and Pagano." NBER Macroeconomics Annual 1990:111-16.

- 1993. "Suggestion for a New Set of Fiscal Indicators." Working paper, OECD, Paris.

$\rightarrow$ Blanchard, Olivier J., and Roberto Perotti. 2002. "An Empirical Investigation of the Dynamic Effects of Changes in Government Spending and Revenues on Output." Quarterly Journal of Economics 117 (November): 1329-68.

$\rightarrow$ Giavazzi, Francesco, Tullio Jappelli, and Marco Pagano. 2000. "Searching for Non-linear Effects of Fiscal Policy: Evidence from Industrial and Developing Countries." European Economic Review 44, no. 7:1259-89.

Giavazzi, Francesco, and Marco Pagano. 1990. "Can Severe Fiscal Contractions Be Expansionary? Tales of Two Small European Countries." NBER Macroeconomics Annual 1990:95-122.

Lambertini, Luisa, and José A. Tavares. 2005. "Exchange Rates and Fiscal Adjustments: Evidence from the OECD and Implications for the EMU." Contributions to Macroeconomics 5, no. 1, art. 11. http://www.bepress.com/bejm/ contributions/vol5/iss1/art11.

McDermott, J., and R. Wescott. 1996. “An Empirical Analysis of Fiscal Adjustments." IMF Staff Papers 43, no. 4:723-53.

$\rightarrow$ Milesi-Ferretti, Gian Maria, Roberto Perotti, and Massimo Rostagno. 2002. "Electoral Systems and Public Spending." Quarterly Journal of Economics 117 , no. 2:609-57.

Mountford, A., and H. Uhlig. 2008. "What Are the Effects of Fiscal Policy Shocks?" Working Paper no. 14551, NBER, Cambridge, MA.

Persson, Torsten, and Guido Tabellini. 2003. The Economic Effects of Constitutions. Munich Lectures in Economics. Cambridge, MA: MIT Press.

Ramey, V. 2009. "Identifying Government Spending Shocks: It's All in the Timing." Working Paper no. 15464 (October), NBER, Cambridge, MA.

Romer, Christina, and David Romer. 2007. "The Macroeconomics Effects of Tax Change: Estimates Based on a New Measure of Fiscal Shocks." Working Paper no. 13264, NBER, Cambridge, MA. 
$\rightarrow$ Sutherland, A. 1997. "Fiscal Crises and Aggregate Demand: Can High Public Debt Reverse the Effects of Fiscal Policy?" Journal of Public Economics 65:147-62.

$\rightarrow$ von Hagen, Jurgen, Andrew Hughes Hallett, and Rolf Strauch. 2002. "Budgetary Consolidation in Europe: Quality, Economic Conditions, and Persistence." Journal of the Japanese and International Economies 16:512-35.

von Hagen, Jurgen, and Rolf Strauch. 2001. "Fiscal Consolidations: Quality, Economic Conditions, and Success." Public Choice 109, nos. 3-4:327-46. 